\title{
Copper Recycling in the United States in 2004
}

\author{
By Thomas G. Goonan
}

\section{U.S. GEOLOGICAL SURVEY CIRCULAR 1196-X}




\section{U.S. Department of the Interior \\ KEN SALAZAR, Secretary \\ U.S. Geological Survey \\ Marcia K. McNutt, Director}

U.S. Geological Survey, Reston, Virginia: 2010

For product and ordering information:

World Wide Web: http://www.usgs.gov/pubprod

Telephone: 1-888-ASK-USGS

For more information on the USGS - the Federal source for science about the Earth, its natural and living resources, natural hazards, and the environment:

World Wide Web: http://www.usgs.gov

Telephone: 1-888-ASK-USGS

Any use of trade, product, or firm names is for descriptive purposes only and does not imply endorsement by the U.S. Government.

Although this report is in the public domain, permission must be secured from the individual copyright owners to reproduce any copyrighted materials contained within this report. 


\section{FOREWORD}

As world population increases and the world economy expands, so does the demand for natural resources. An accurate assessment of the Nation's mineral resources must include not only the resources available in the ground but also those that become available through recycling. Supplying this information to decisionmakers is an essential part of the USGS commitment to providing the science that society needs to meet natural resource and environmental challenges.

The U.S. Geological Survey is authorized by Congress to collect, analyze, and disseminate data on the domestic and international supply of and demand for minerals essential to the U.S. economy and national security. This information on mineral occurrence, production, use, and recycling helps policymakers manage resources wisely.

USGS Circular 1196, "Flow Studies for Recycling Metal Commodities in the United States," presents the results of flow studies for recycling 26 metal commodities, from aluminum to zinc. These metals are a key component of the U.S. economy. Overall, recycling accounts for a significant portion of U.S. metal supply.

Marcia K. McNutt

Director 


\section{CONTENTS}

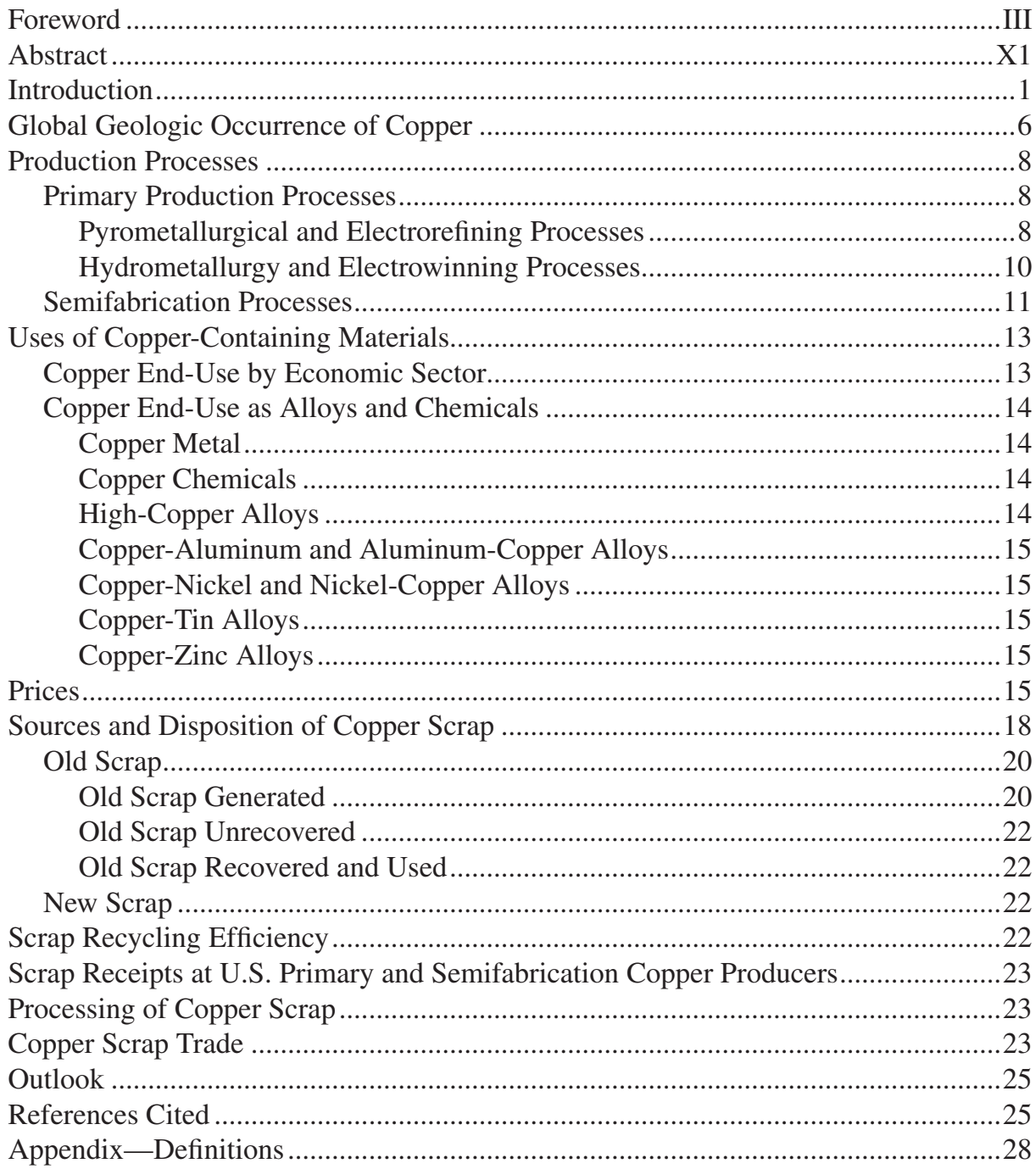




\section{FIGURES}

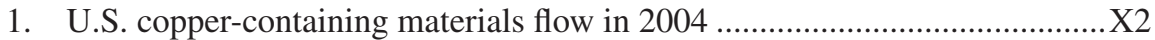

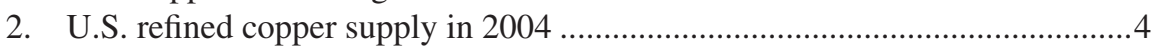

3. Copper flow to and through semifabrication producers in 2004 ......................5

4. Pyrometallurgical smelting and electrorefining process steps ..........................

5. Hydrometallurgical solvent-extraction and electrowinning process.................10

6. Process flow chart (unquantified) for copper scrap .........................................11

7. U.S. end-use consumption, by economic sector, from 1980 through 2004 ....13

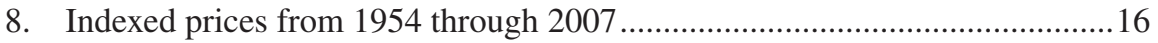

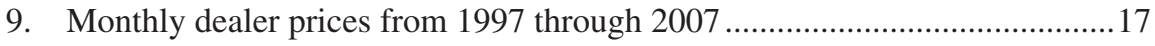

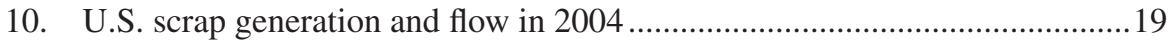

11. U.S. exports of old copper scrap, by country, in 2004..................................24

12. Chinese imports of U.S. old copper scrap from 1995 through 2004 ..............24

13. U.S. imports of old copper scrap, by country, in $2004 \ldots \ldots \ldots \ldots \ldots \ldots \ldots \ldots \ldots \ldots \ldots . . . . .25$

\section{TABLES}

1. Salient copper flow statistics for the United States in $2004 \ldots \ldots \ldots \ldots \ldots \ldots \ldots \ldots \ldots . . . . .33$

2. Principal characteristics of significant porphyry copper deposits .................... 7

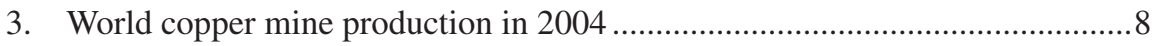

4. Average annual growth rates for U.S. consumption of copper .........................14

5. Copper scrap classifications and most likely users........................................18

6. The development of the estimate for old scrap generated in 2004 ..................20 


\section{CONVERSION FACTORS}

\begin{tabular}{rll}
\hline \multicolumn{1}{c}{ Multiply } & By & To obtain \\
\hline micrometer $(\mu \mathrm{m})$ & $\begin{array}{c}\text { Length } \\
\text { inch }(\mathrm{in} .)\end{array}$ & $\begin{array}{l}\text { inch (in.) } \\
\text { centimeter }\end{array}$ \\
& 2.54 & \\
cubic meter $\left(\mathrm{m}^{3}\right)$ & \multicolumn{1}{l}{ Volume } & cubic foot $\left(\mathrm{ft}^{3}\right)$ \\
& 35.31 & \\
& Mass & ounce avoirdupois $(\mathrm{oz})$ \\
microgram $(\mu \mathrm{g})$ & 0.00000003527 & pound $(\mathrm{lb})$ \\
kilogram $(\mathrm{kg})$ & 2.205 & short ton $(2,000$ pounds) \\
metric ton $(\mathrm{t}, 1,000 \mathrm{~kg})$ & 1.102 & megagram $(\mathrm{Mg})$ or metric ton $(\mathrm{t})$ \\
ton, short $(2,000 \mathrm{lb})$ & 0.9072 & \\
\hline
\end{tabular}

Temperature in degrees Celsius $\left({ }^{\circ} \mathrm{C}\right)$ may be converted to degrees Fahrenheit $\left({ }^{\circ} \mathrm{F}\right)$ as follows:

${ }^{\circ} \mathrm{F}=\left(1.8 x^{\circ} \mathrm{C}\right)+32$

Temperature in degrees Fahrenheit $\left({ }^{\circ} \mathrm{F}\right)$ may be converted to degrees Celsius $\left({ }^{\circ} \mathrm{C}\right)$ as follows:

${ }^{\circ} \mathrm{C}=\left({ }^{\circ} \mathrm{F}-32\right) / 1.8$ 


\title{
FLOW STUDIES FOR RECYCLING METAL COMMODITIES IN THE UNITED STATES
}

\section{Copper Recycling in the United States in 2004}

\author{
By Thomas G. Goonan
}

\begin{abstract}
As one of a series of reports that describe the recycling of metal commodities in the United States, this report discusses the flow of copper from production through distribution and use, with particular emphasis on the recycling of industrial scrap (new scrap ${ }^{1}$ ) and used products (old scrap) in the year 2004. This materials flow study includes a description of copper supply and demand for the United States to illustrate the extent of copper recycling and to identify recycling trends. Understanding how materials flow from a source through disposition can aid in improving the management of natural resource delivery systems.

In 2004, the U.S. refined copper supply was 2.53 million metric tons $(\mathrm{Mt})$ of refined unalloyed copper. With adjustment for refined copper exports of 127,000 metric tons ( $t$ ) of copper, the net U.S. refined copper supply was $2.14 \mathrm{Mt}$ of copper. With this net supply and a consumer inventory decrease of 9,000 t of refined copper, $2.42 \mathrm{Mt}$ of refined copper was consumed by U.S. semifabricators (brass mills, wire rod mills, ingot makers, and foundries and others) in 2004.

In addition to the $2.42 \mathrm{Mt}$ of refined copper consumed in 2004, U.S. copper semifabricators consumed $853,000 \mathrm{t}$ of copper contained in recycled scrap. Furthermore, 61,000 t of copper contained in scrap was consumed by noncopper alloy makers, for example, steelmakers and aluminum alloy makers.

In 2004, 3.20 Mt of copper was delivered to U.S. manufacturers. Of this amount, about 22 percent $(699,000$ t) was recycled as manufacturing or new scrap, and 78 percent $(2.50 \mathrm{Mt})$ entered the U.S. copper products reservoir. From the same reservoir, $1.92 \mathrm{Mt}$ of copper as old scrap theoretically became available (by reaching theoretical end of life), a net gain to the reservoir of $578,000 \mathrm{t}$ of copper contained in products having a useful life. Of the $1.92 \mathrm{Mt}$ of copper contained in old scrap generated, about 40 percent $(772,000$ t) was recovered, and 60 percent $(1.15 \mathrm{Mt})$ was unrecovered.

In 2004, the 772,000 t of copper contained in old scrap recovered was supplemented by $80,000 \mathrm{t}$ of copper contained in imports of old scrap and 3,000 $\mathrm{t}$ of copper contained in an old
\end{abstract}

${ }^{1}$ Definitions for selected words and terms are found in the Appendix. scrap stock decrease to produce an old scrap supply containing $855,000 \mathrm{t}$ of copper. This supply of contained copper was distributed as $633,000 \mathrm{t}$ to old scrap exports (74 percent of supply), 167,000 $\mathrm{t}$ to U.S. copper processor receipts (20 percent of supply), and 54,000 $\mathrm{t}$ for U.S. noncopper processor receipts (6 percent of supply).

In 2004, collection and receipts of new scrap amounted to $735,000 \mathrm{t}$ of contained copper, which was consumed in U.S. production of copper-containing products. A total of $965,000 \mathrm{t}$ of copper contained in copper scrap was consumed by U.S. production activities, of which 88 percent $(845,000 \mathrm{t})$ was consumed by semifabrication copper producers, 7 percent was consumed by noncopper producers, and 5 percent $(51,000$ t) was consumed by primary copper production.

In 2004, the old scrap recycling efficiency for copper was estimated to be 43 percent of theoretical old scrap supply, the recycling rate for copper was 30 percent of apparent supply, and the new-scrap-to-old-scrap ratio for U.S. copper product production was 3.2 (76:24).

\section{INTRODUCTION}

Copper has been used by humans for more than 10,000 years. There is evidence of copper smelting in the Middle East around 5000 BCE. On average, between 13 million and 14 million metric tons of copper worldwide was added each year into usage from mine production for the years 2000 through 2004. This study provides a snapshot, shown in figure 1 , of the flow through the U.S. economy of recoverable copper contained in various copper-containing materials in 2004. It identifies sources of the U.S. copper supply and its distribution with particular emphasis on the flow ${ }^{2}$ of copper contained in scrap. Figure 1 provides an overall view of the flow of copper and copper-bearing materials through the economy of the United States for 2004.

In 2004, copper semifabricators (brass and wire rod mills, ingot makers, and foundries and other manufacturing)

\footnotetext{
${ }^{2}$ As a general rule, flow information (numbers associated with arrows in the diagrams) is derived from disparate data sources with differing levels of quality and is not as precise as the reporting might indicate. One should view the reported values relative to each other rather than for the precision of the data.
} 


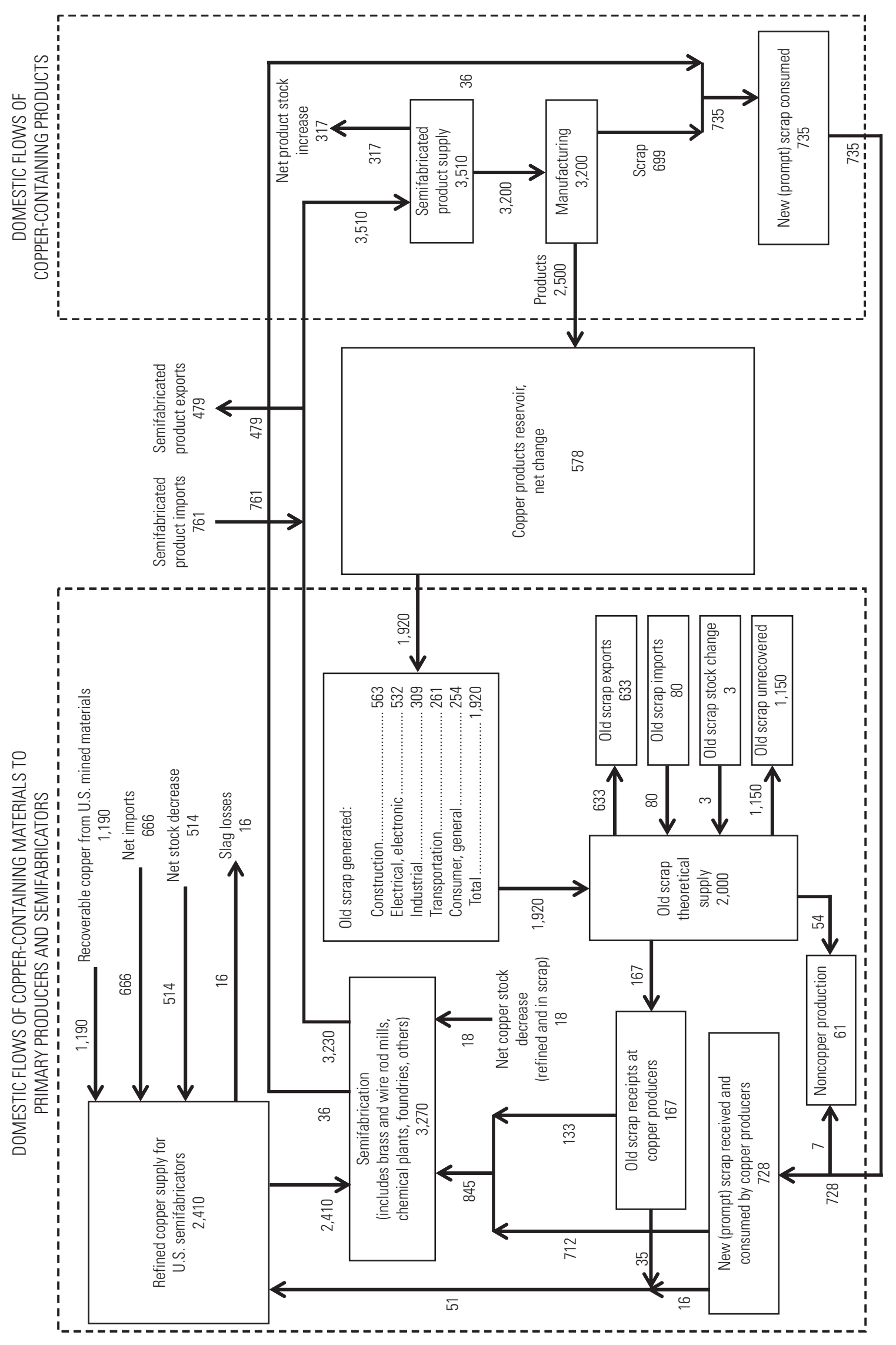

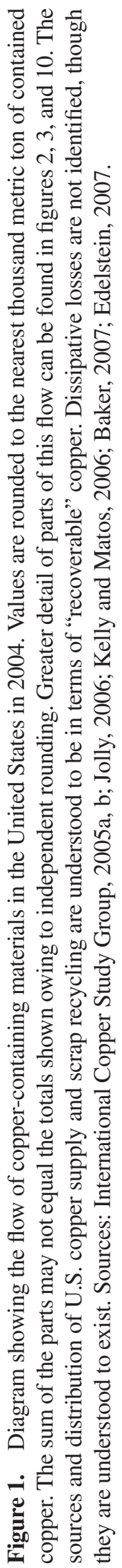


consumed 2.42 Mt of refined copper in their operations. For the purposes of this study, even though the semifabrication sector called foundries and others produces both finished and semifabricated products, the entire production of the sector is attributed to semifabrication of copper and copper alloy products. Semifabricators consumed 853,000 metric tons (t) of scrap copper, which amounted to a total consumption of copper by semifabricators of $3.27 \mathrm{Mt}$. Semifabricators generated new scrap containing 36,000 t of copper. Therefore, the net flow of copper from U.S. semifabricators was 3.23 Mt of copper in 2004, which was augmented by imports that contained 761,000 t of copper and was depleted by exports that contained 479,000 t of copper such that the supply of semifabricated copper products contained 3.51 Mt of copper in 2004. This supply of semifabricated copper products was distributed as $3.20 \mathrm{Mt}$ of copper (91 percent of supply) to U.S. manufacturers and 317,000 t (9 percent of supply) to a product stock increase.

Manufacturing of copper products generated new scrap, which contained 699,000 $t$ of copper (22 percent of manufacturing throughput), and useful products for the U.S. copper products reservoir, ${ }^{3}$ which contained $2.50 \mathrm{Mt}$ of copper. The product reservoir theoretically (estimate details are discussed below) generated 1.92 Mt of copper as old scrap, 40 percent of which was recovered and 60 percent of which was unrecovered (unaccounted flows to landfills, stocks left-in-place, and dissipative losses).

After adjustments for imports and stock changes, the U.S. theoretical supply of old scrap contained 2.00 Mt of copper, of which 1.15 Mt was unrecovered and 855,000 t represented actual supply of copper contained in old scrap. Most of the recovered copper, 633,000 t of copper (74 percent), was exported. Of the remaining 26 percent, 167,000 $t$ of copper (20 percent of recovered copper) was recovered at U.S. smelters and semifabricators, and 54,000 t of contained copper (6 percent) was recovered by noncopper producers. Most of the 633,000 t of copper that was exported went to Asia, particularly China. Copper contained in exported scrap was assumed to be 100 percent recovered in the recipient countries.

Smelters, refiners, and semifabricators recovered $728,000 \mathrm{t}$ of copper from new scrap and 167,000 $\mathrm{t}$ of copper from old scrap. Smelters and refiners recovered 6 percent of copper contained in recycled scrap, and semifabricators recovered 94 percent.

In 2004, the old scrap recycling efficiency for copper was estimated to be 43 percent of theoretical old scrap supply, the recycling rate for copper was 30 percent of U.S. apparent copper supply, and the new-scrap-to-old-scrap consumption

\footnotetext{
${ }^{3}$ This addition to the U.S. copper product reservoir is trade adjusted for semifabricated products but does not include any adjustment for net imports of assembled products that may contain copper (for example, automobiles and appliances).
}

ratio for U.S. copper product production was approximately 3.2. Salient copper flow statistics for 2004 are summarized in table 1 .

Table 1. Salient copper flow statistics for the United States in 2004.

[Values are in thousand metric tons of contained copper, unless otherwise specified. Sources: International Copper Study Group, 2005a, b; Jolly, 2006; Kelly and Matos, 2006; Baker, 2007; Edelstein, 2007]

\begin{tabular}{|c|c|}
\hline Old scrap theoretically generated...... & 1,920 \\
\hline Old scrap consumed (received \pm inventory change) .................. & 230 \\
\hline Value of old scrap consumed & $\$ 305$ million \\
\hline 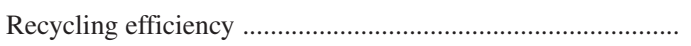 & 43.1 percent \\
\hline Old scrap supply ............ & 2,000 \\
\hline Old scrap unrecovered ............. & 1,150 \\
\hline New scrap generated and consumed... & 735 \\
\hline New-to-old-scrap ratio ............................. & $76: 24$ \\
\hline Recycling rate ................... & 29.9 percent \\
\hline U.S. net exports of scrap ......................... & 553 \\
\hline Value of U.S. net exports of scrap ....... & $\$ 694$ million \\
\hline Apparent consumption ....................... & 2,500 \\
\hline $\begin{array}{l}\text { Refined-to-scrap-borne-copper ratio for U.S. copper } \\
\text { consumption }\end{array}$ & 71:29 \\
\hline Apparent supply & 3,230 \\
\hline
\end{tabular}

Figure 2 shows the sources and distribution of U.S. refined copper supply in 2004.

The sources for the estimated flow of refined (unalloyed) copper to U.S. copper processors are U.S. mining operations (adjusted for slag losses), 49 percent; net imports of various copper-bearing materials (anode, ash, blister, concentrate, matte, ore, and refined copper), 28 percent; stock decreases (producer stocks, including anode and blister stocks, exchange stocks, mine stocks, and refinery stocks), 21 percent; and scrap, 2 percent. U.S. copper-refining operations produced 1.31 Mt of unalloyed copper (45 percent electrowon, 51 percent electrorefined, and 4 percent fire refined). With adjustment of refined-copper production for net imports $(577,000 \mathrm{t}$ of copper) and net stock decreases (522,000 t of copper), the total net refined-copper flow to U.S. semifabricators was 2.41 Mt of copper in 2004.

Figure 3 shows in detail the flows of refined copper and recycled copper (contained in scrap) to and through U.S. semifabricators.

Brass mills consumed 1.26 Mt of copper, of which 45 percent was refined copper, 54 percent was from copper contained in scrap, and 1 percent was copper contained in ingot (essentially from scrap). Adjusting for 174,000 t of copper contained in net imports, 64,000 t of copper contained in a brass mill stock decrease, and 20,000 t of copper contained in new scrap generated, $1.48 \mathrm{Mt}$ of copper contained in brass mill products was supplied to U.S. manufacturers. 


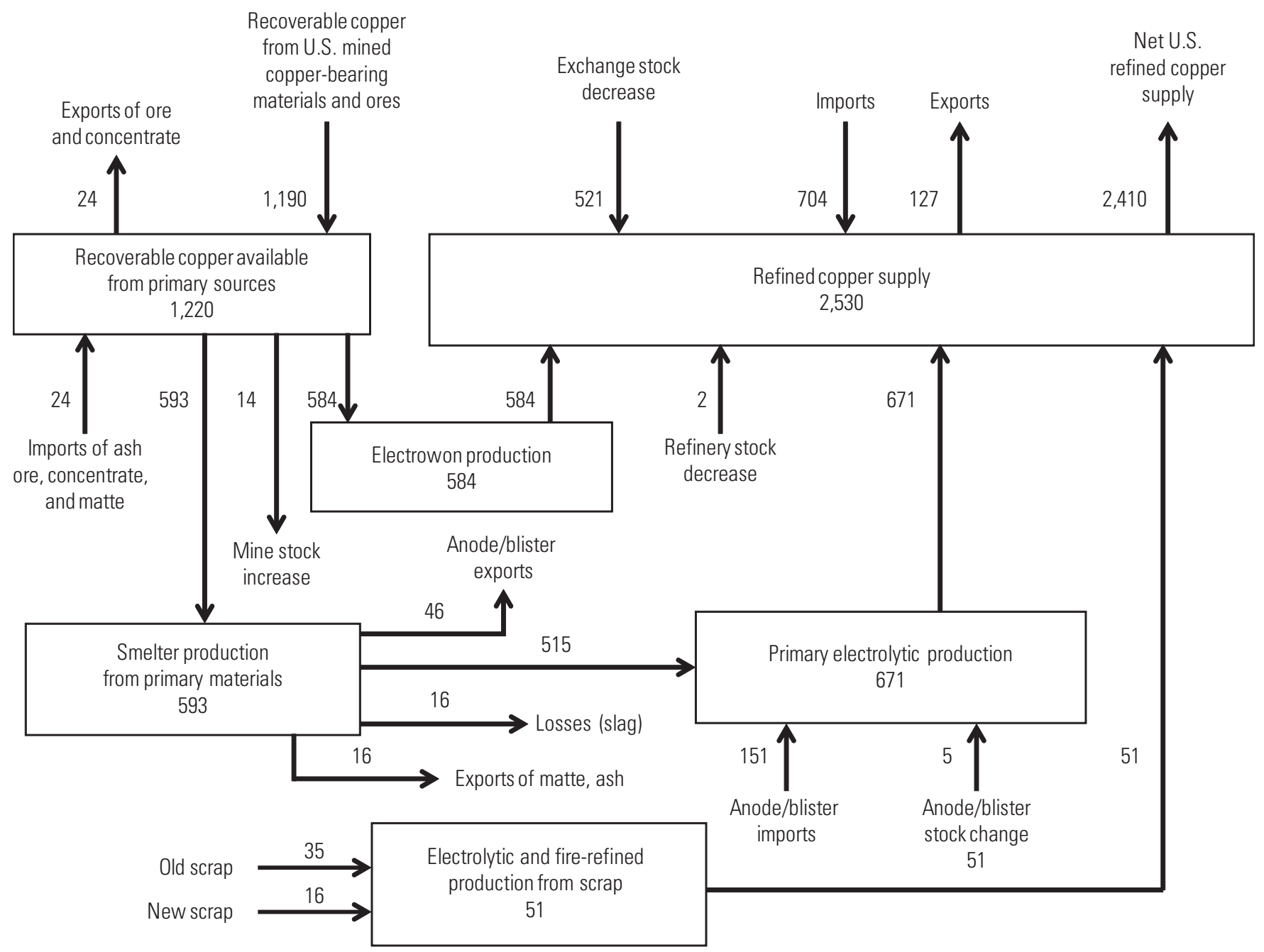

Figure 2. Diagram showing sources and distribution of U.S. refined copper supply in 2004. Values are rounded to the nearest thousand metric ton of contained copper. The sum of the parts may not equal the totals shown owing to independent rounding. The sources and distribution of U.S. copper supply and scrap recycling are understood to be in terms of "recoverable" copper. Dissipative losses are not identified, though they are understood to exist. Sources: International Copper Study Group, 2005a, b; Jolly, 2006; Kelly and Matos, 2006; Baker, 2007; Edelstein, 2007.

Wire semifabrication ${ }^{4}$ consumed $1.81 \mathrm{Mt}$ of copper, of which 98 percent was refined copper and 2 percent was scrap copper. Net imports of wire rod and wire mill products (taken together) contained $67,000 \mathrm{t}$ of copper (113,000 $\mathrm{t}$ of copper contained in net imports of wire rod minus 46,000 t of copper contained in net exports of wire). Stocks, in contained copper terms, at wire rod mills increased by $16,000 \mathrm{t}$ and, at wire mills, by $273,000 \mathrm{t}-\mathrm{a}$ total of $289,000 \mathrm{t}$. Therefore, the flow of copper to U.S. manufacturers of copper contained in wire product was $1.58 \mathrm{Mt}$ in 2004.

${ }^{4}$ Depending on the use, wire may be considered to be a semifabricated or manufactured product. In this report, wire is considered to be the semifabricated product of a two-step process-wire rod-making and wiremaking from trade and stock adjusted rod production.
Ingot makers consumed 95,000 $t$ of copper, 5 percent of which was refined copper, and 95 percent was from copper contained in scrap. After generating 5,000 t of copper contained in process scrap, 91,000 $\mathrm{t}$ of copper in ingot products (ingots, hardeners, and master alloys) was distributed to brass mills, of which 81,000 t (89 percent) of copper went to foundries and others, and 10,000 t (11 percent) went to brass mills.

Foundries and others (chemical plants and powder manufacturers) consumed 196,000 t of copper, of which 41 percent was contained in ingot (essentially from scrap), 30 percent was scrap copper, and 29 percent was refined copper. After generating 11,000 t of copper contained in process scrap, 186,000 $\mathrm{t}$ of copper contained in foundries and other products was enhanced with 40,000 $t$ of copper contained in net imports and depleted by $94,000 \mathrm{t}$ of copper 


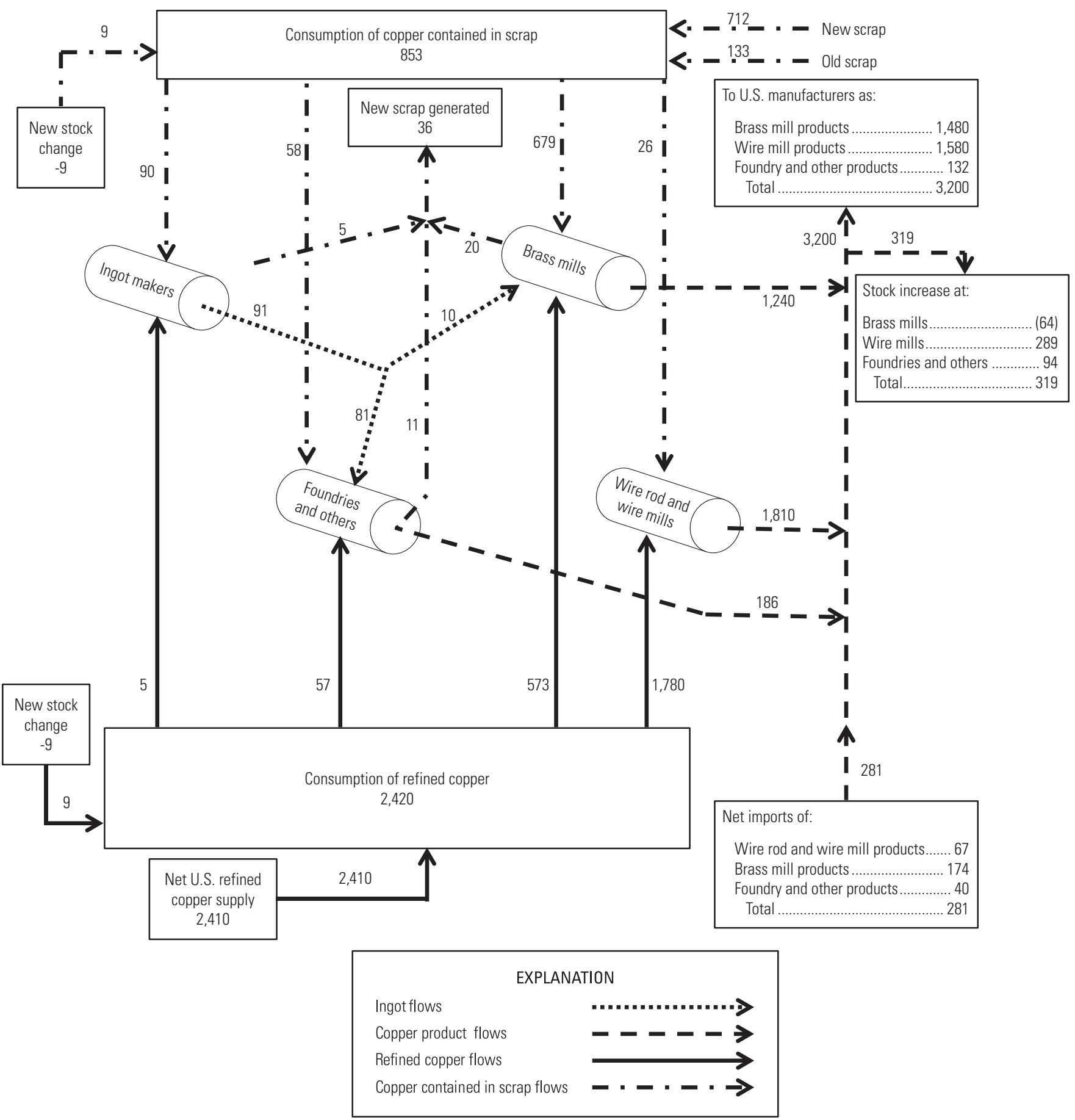

Figure 3. Diagram showing the flow of refined and scrap copper to and through semifabrication copper producers in 2004. Values are rounded to the nearest thousand metric ton of contained copper. The sum of the parts may not equal the totals shown owing to independent rounding. The sources and distribution of U.S. copper supply and scrap recycling are understood to be in terms of "recoverable" copper. Dissipative losses are not identified, though they are understood to exist. Sources: International Copper Study Group, 2005a, b; Jolly, 2006; Kelly and Matos, 2006; Baker, 2007; Edelstein, 2007. 
contained in product stock increases, such that $132,000 \mathrm{t}$ of copper flowed to U.S. manufacturers for further processing.

\section{GLOBAL GEOLOGIC OCCURRENCE OF COPPER}

Copper is a chemical element of group II-B of the periodic table; it has atomic number 29 and atomic weight of 63.546, consisting of isotopes ${ }^{63} \mathrm{Cu}(69.09$ percent) and ${ }^{65} \mathrm{Cu}$ (30.91 percent) (Cox and others, 1973). It occurs in nature as the native element, as compounds of $\mathrm{Cu}^{+1}$ and $\mathrm{Cu}^{+2}$. Copper is a strongly sulfur-seeking (chalcophile) element, and it tends to be concentrated in sulfide deposits; in igneous rocks, it occurs mainly as finely divided sulfides, principally chalcopyrite and bornite. Copper is concentrated in basaltic and gabbroic igneous rock [30-160 parts per million (ppm), average $90 \mathrm{ppm}$ ] and in sedimentary clays, sandstones, shales, and soils (2-120 ppm, average $45 \mathrm{ppm})$. The crustal abundance for copper is about 50 ppm (Parker, 1967).

Copper occurs in at least 160 minerals. In order of abundance, chalcopyrite $\left(\mathrm{CuFeS}_{2}\right)$, bornite $\left(\mathrm{Cu}_{5} \mathrm{FeS}_{5}\right)$, and chalcocite $\left(\mathrm{Cu}_{2} \mathrm{~S}\right)$ are the principal ore minerals. The sulfarsenides enargite $\left(\mathrm{Cu}_{3} \mathrm{AsS}_{4}\right)$ and tennantite $\left[(\mathrm{Cu}, \mathrm{Fe})_{12} \mathrm{As}_{4} \mathrm{~S}_{13}\right]$ and the sulfantimonides tetrahedrite $\left[(\mathrm{Cu}, \mathrm{Fe})_{12} \mathrm{SbS}_{13}\right]$ and famatinite $\left(\mathrm{Cu}_{3} \mathrm{SbS}_{4}\right)$ are generally rare, but each makes up a major part of at least one large orebody. Malachite $\left[\mathrm{Cu}_{2}(\mathrm{OH})_{2}\left(\mathrm{CO}_{3}\right)\right]$, azurite $\left[\mathrm{Cu}_{3}(\mathrm{OH})_{2}\left(\mathrm{CO}_{3}\right)_{2}\right]$, and chrysocolla $\left[\mathrm{CuSiO}_{3} \cdot 5 \mathrm{H}_{2} \mathrm{O}\right]$ are the most common copper minerals in weathered and oxidized environments (Cox and others, 1973).

Most copper deposits fall into one of the following five major types:

1. porphyry copper deposits and vein and replacement deposits, which account for almost two-thirds of the world's copper resources and are discussed together because of their common genetic association with granitic and intermediate intrusive rocks;

2. sedimentary rocks, which account for one-quarter of the world's identifiable resources;

3. volcanic rocks, such as massive sulfide deposits, which account for about 5 percent of the world's resources;

4. nickel-copper ores formed by magmatic processes in mafic intrusives contain smaller portions of the world resources;

5. in native copper ores of the Keweenaw type.

Porphyry copper deposits, which are characterized by large mass, relatively uniform dissemination, and averageper-ton (often less that 1 percent) copper content (U.S. Bureau of Mines, 1968, p. 848), are typical in the Southwestern United States. They contain upwards of $150 \mathrm{Mt}$ of ore that averages 0.8 percent copper and 0.15 percent molybdenum. On average, 70 percent of the ore body is in the intrusive rock, and 30 percent is in the country rock. Sulfide minerals in descending order of abundance are pyrite $(\mathrm{FeS})$, chalcopyrite $\left(\mathrm{CuFeS}_{2}\right)$, molybdenite $\left(\mathrm{MoS}_{2}\right)$, and bornite $\left(\mathrm{Cu}_{5} \mathrm{FeS}_{5}\right)(\mathrm{Cox}$ and others, 1973).

The U.S. Geological Survey (USGS) has published a database of world porphyry copper deposits (Singer and others, 2002). Table 2 lists some of the principal characteristics of the world's largest porphyry copper deposits.

Vein, pipe, and replacement deposits may be associated with porphyry deposits or may be found within otherwise barren felsic intrusive rocks. According to Cox and others (1973, p. 171-173):

"Veins are formed when metal-rich solutions, emanating from a crystallizing intrusion, deposit minerals in faults or fractures. They are tabular in form and may show mineral textures indicating growth of crystals in open cavities as well as replacement of wallrocks ${ }^{5}$ by copper minerals. Many veins show several generations of mineral deposition related to opening and reopening fault zones by tectonic movements. Hydrothermal alteration envelopes may accompany the veins, indicating chemical reactions between wallrocks and hydrothermal solutions.

"Ore pipes are rodlike in form as contrasted to tubular veins. They may form in fractured or brecciated rock at the intersections of faults or by explosive release of gases derived from intrusive magmas. These latter are called breccia pipes because of the broken rock associated with them. At many places copper deposits in breccia pipes show a close spatial and genetic relation to porphyry intrusions....

"Replacement deposits form in reactive host rocks near the intrusive contacts or along mineral veins. These hosts may be sedimentary rocks such as limestone, dolomite, or calcareous ${ }^{6}$ sandstone or even diabase sills... . Replacement deposits tend to be tabular in form... . Vein, pipe, and replacement deposits have a more varied mineralogy than porphyry deposits. Calchopyrite and bornite are the most common hypogene $e^{7}$ minerals... .

"Strata-bound deposits in sedimentary rocks include some of the world's largest sources of copper $^{8} . .$. ."

The stratabound copper deposits can be from new sediments or old sediments enclosed by new sediments. Additionally, there can be mineral alterations caused by precipitation from solutions or chemical reactions, such as oxidation or reduction. The type of alteration is governed by gradients of $\mathrm{pH}$, pressure, temperature, and other physical conditions within the sediments.

\footnotetext{
${ }^{5}$ Wallrock is the country rock immediately adjacent to the vein or load.

${ }^{6} \mathrm{Calcareous}$ rocks are ones containing limestone.

${ }^{7}$ Hypogene are mineral deposits that are formed by ascending hot waters.

${ }^{8}$ These are Congo (Brazzaville) (formerly Zaire), Russia, and Zambia.
} 
Table 2. Principal characteristics of the world's most significant porphyry copper deposits.

[Values are in metric tons of contained copper, unless otherwise specified. NA, not available; XX, not applicable. Source: Singer and others 2002]

\begin{tabular}{|c|c|c|c|c|c|c|c|}
\hline Deposit name & $\begin{array}{c}\text { Discovery } \\
\text { year }\end{array}$ & $\begin{array}{c}\text { Startup } \\
\text { year }\end{array}$ & $\begin{array}{c}\text { Age, } \\
\text { in millions of } \\
\text { years }\end{array}$ & $\begin{array}{c}\text { Tonnage, } \\
\text { in millions } \\
\text { of metric } \\
\text { tons of ore }\end{array}$ & $\begin{array}{c}\text { Grade, } \\
\text { in percent of } \\
\text { copper }\end{array}$ & $\begin{array}{c}\text { Tonnage, } \\
\text { in percent of } \\
\text { known porphyry } \\
\text { deposits }\end{array}$ & $\begin{array}{c}\text { Tonnage, } \\
\text { in cumulative } \\
\text { percent of known } \\
\text { porphyry deposits }\end{array}$ \\
\hline Chuquicamata ................. Chile ..................... & 1911 & 1915 & 31.5 & 17,100 & 0.65 & 7.37 & 7.37 \\
\hline 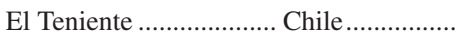 & 1706 & 1906 & 4.5 & 11,800 & 0.92 & 5.09 & 12.46 \\
\hline Safford........................... United States ... & 1886 & 1959 & 52.5 & 7,260 & 0.44 & 3.13 & 15.59 \\
\hline Cananea.......................... Mexico ............. & NA & 1899 & 55.5 & 7,140 & 0.42 & 3.08 & 18.67 \\
\hline Morenci-Metcalf ............ United States ... & 1872 & 1942 & 56.0 & 6,470 & 0.52 & 2.79 & 21.46 \\
\hline Almalyk......................... Uzbekistan........ & 1925 & 1958 & 289.5 & 6,080 & 0.39 & 2.62 & 24.08 \\
\hline Continental/Butte .......... United States ... & NA & 1864 & 60.5 & 5,220 & 0.67 & 2.25 & 26.33 \\
\hline 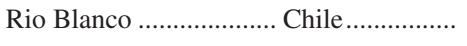 & 1864 & 1970 & 6.0 & 5,000 & 0.80 & 2.16 & 28.29 \\
\hline La Escondida................... Chile ..................... & 1981 & 1990 & 35.0 & 4,860 & 0.97 & 2.10 & 30.58 \\
\hline 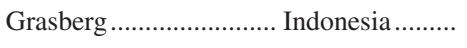 & 1936 & 1973 & 3.0 & 4,000 & 0.60 & 1.72 & 32.31 \\
\hline Cerro Colorado............... Chile ................... & 1970 & NA & 5.0 & 3,730 & 0.39 & 1.61 & 33.92 \\
\hline 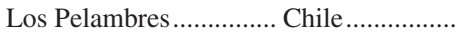 & 1914 & 1992 & 9.5 & 3,300 & 0.63 & 1.42 & 35.34 \\
\hline Bingham Canyon .......... United States ... & 1863 & 1904 & 36.0 & 3,230 & 0.88 & 1.39 & 36.73 \\
\hline Ray .................................... United States ... & 1846 & 1911 & 60.5 & 3,230 & 0.49 & 1.39 & 38.12 \\
\hline Aktogai........................... Kazakhstan....... & NA & NA & 333.0 & 3,120 & 0.39 & 1.38 & 39.50 \\
\hline Collahausi ....................... Chile ..................... & 1978 & 1999 & 32.0 & 3,100 & 0.86 & 1.34 & 40.84 \\
\hline Chino ............................ United States ... & 1801 & 1911 & 55.5 & 3,030 & 0.47 & 1.31 & 42.15 \\
\hline La Granja ..................... Peru .................. & 1969 & NA & 12.0 & 3,000 & 0.56 & 1.29 & 43.44 \\
\hline Tampakan ........................ Philippines......... & NA & NA & NA & 2,500 & 0.48 & 1.08 & 44.52 \\
\hline 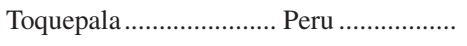 & NA & 1959 & 57.0 & 2,320 & 0.55 & 1.00 & 45.52 \\
\hline Sierrita ............................. United States ... & 1895 & 1907 & 55.0 & 1,830 & 0.26 & 0.79 & 46.31 \\
\hline La Caridad....................... Mexico .............. & 1896 & 1905 & 51.0 & 1,800 & 0.45 & 0.78 & 47.08 \\
\hline Glacier Peak $^{1} \ldots \ldots \ldots \ldots \ldots . . .$. United States .... & 1900 & NA & 21.0 & 1,710 & 0.33 & 0.74 & 47.82 \\
\hline Agua Rica....................... Argentina........... & 1900 & 1965 & 5.5 & 1,710 & 0.43 & 0.74 & 48.56 \\
\hline 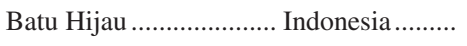 & 1987 & 1999 & 3.7 & 1,640 & 0.44 & 0.71 & 49.27 \\
\hline 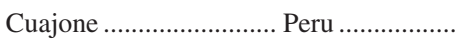 & 1939 & 1976 & 51.0 & 1,630 & 0.69 & 0.70 & 49.97 \\
\hline Subtotal $(26) \ldots \ldots \ldots \ldots . .$. & $\mathrm{XX}$ & $\mathrm{XX}$ & $\mathrm{XX}$ & 116,000 & ${ }^{2} 0.57$ & 49.97 & $\mathrm{XX}$ \\
\hline Others (355) ................. Worldwide....... & $\mathrm{XX}$ & $\mathrm{XX}$ & $\mathrm{XX}$ & 116,000 & ${ }^{2} 0.49$ & 50.03 & 100.00 \\
\hline Total (381) .................. Worldwide........ & $\mathrm{XX}$ & $\mathrm{XX}$ & $\mathrm{XX}$ & 232,000 & ${ }^{2} 0.50$ & 100.00 & 100.00 \\
\hline
\end{tabular}

${ }^{1}$ This deposit will not be developed because it is within the Glacier Peak Wilderness Area, Wash.

${ }^{2}$ Average for the deposits within the group.

Massive sulfide deposits are typically found in volcanic rocks. Copper is more abundant in basalt (highest relative calcium content) and andesite (next highest relative calcium content) than in other volcanic rocks. A small but locally important part of the world's copper resources is found in lava flows and pyroclastic rocks deposited in the marine environment. Different magma chemistries give rise to deposits of different mineralogy. For example, pyritepyrrhotite-chalcopyrite (iron-copper-sulfur systems) deposits are commonly associated with mafic volcanics, and sphalerite (zinc-sulfur)- and galena (lead-sulfur)-bearing deposits tend to be found in silicic volcanic rocks (Cox and others, 1973, p. 179).
Copper and nickel ores of commercial grade are found in mafic rocks, and the copper is a byproduct of nickel production. Australia, Canada, and Russia produce byproduct copper in this fashion. Such deposits are generally interpreted to have been formed by a magmatic-segregation process as part of the intrusion of the bodies of mafic rock. Variation in the nickel-to-copper ratio in different ore bodies makes it possible for the mining company to adapt the ratio in the ore produced to metal-market conditions (Cox and others, 1973, p. 179).

Native copper (Keweenaw type) deposits are stratabound, having been introduced into vesicles, fractures, and interstitial pore spaces after deformation of the rocks (Cox and others, 
Table 3. World copper mine production in 2004, by type of production and country.

[-, zero. Calculated from original data reported by Edelstein, 2007, p. 21.29-21.30]

\begin{tabular}{|c|c|c|c|c|c|}
\hline \multirow{2}{*}{ Country } & \multicolumn{3}{|c|}{ Copper content, in metric tons of contained copper } & \multirow{2}{*}{$\begin{array}{l}\text { Percentage of } \\
\text { world production }\end{array}$} & \multirow{2}{*}{$\begin{array}{l}\text { Cumulative } \\
\text { percentage }\end{array}$} \\
\hline & Concentrate production & Electrowon production & Total production & & \\
\hline Chile ................................. & $3,780,000$ & $1,640,000$ & $5,410,000$ & 36.95 & 36.95 \\
\hline United States ${ }^{1} \ldots \ldots \ldots \ldots \ldots . . . . . .$. & 576,000 & 584,000 & $1,160,000$ & 7.92 & 44.86 \\
\hline Peru & 869,000 & 167,000 & $1,040,000$ & 7.07 & 51.93 \\
\hline Australia ........................... & 796,000 & 58,300 & 854,000 & 5.83 & 57.76 \\
\hline Indonesia ......................... & 840,000 & - & 840,000 & 5.74 & 63.50 \\
\hline 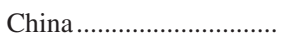 & 742,000 & 10,000 & 752,000 & 4.61 & 68.11 \\
\hline 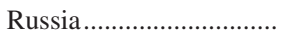 & 675,000 & - & 675,000 & 5.06 & 73.17 \\
\hline Canada............................. & 563,000 & - & 563,000 & 3.85 & 77.02 \\
\hline Poland ….......................... & 531,000 & - & 531,000 & 3.62 & 80.64 \\
\hline Kazakhstan ......................... & 461,000 & - & 461,000 & 3.15 & 83.79 \\
\hline 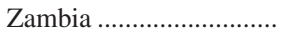 & 344,000 & 82,600 & 427,000 & 2.91 & 86.70 \\
\hline 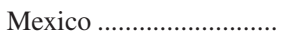 & 334,000 & 72,200 & 406,000 & 2.77 & 89.47 \\
\hline 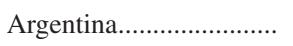 & 177,000 & - & 177,000 & 1.21 & 90.68 \\
\hline Other & $1,310,000$ & 87,600 & $1,400,000$ & 9.32 & 100.00 \\
\hline Total ……..................... & $11,900,000$ & $2,770,000$ & $14,700,000$ & 100.00 & \\
\hline
\end{tabular}

${ }^{1}$ Recoverable copper content.

1973, p. 179-180). While copper mining in the Keweenaw [Mich.] province is presently inactive, the copper resource is still extensive.

Table 3 lists 2004 worldwide copper mine production distributed by type of production and by country. Table 3 also shows the worldwide recovery of copper from leached ores (hydrometallurgy) in 2004.

In 2004, 13 countries accounted for nearly 91 percent of world copper production. Chile, which has the largest deposits, also has the highest grade deposits $(0.74$ percent average copper, versus the average for all porphyry copper deposits of 0.50 percent copper). Chile produced about 37 percent, which is more than four times the amount of the next largest producer, the United States.

Chile also leads the world in the production of copper from leached ore (1.64 Mt of copper), but the percentage of total Chilean production as electrowon copper is only 30 percent. Electrowinning is a process that recovers copper leached from copper oxide and sulfide ores.

The United States, which had copper mine production (concentrates, adjusted for $16,000 \mathrm{t}$ copper in slag loss, and electrowon) of $1.18 \mathrm{Mt}$ of copper, was the number two producer of copper in the world in 2004. However, production in the United States was only one-fifth that of Chile. The United States is a major producer of copper concentrates (about 4 percent of total world mined copper production) and leads the world in the percentage of total copper produced as electrowon copper (50 percent). The United States does import copper because it is economically efficient to do so, but it can function as import independent.

\section{PRODUCTION PROCESSES}

\section{PRIMARY PRODUCTION PROCESSES}

Copper ore is generally processed either by a pyrometallurgical route (application of heat) or by hydrometallurgical (treatment of copper-bearing solutions) methods to produce a suitable feedstock for refining by electrical methods to ultimately obtain refined copper of greater than 99.9 percent purity (Anchor Bronze and Metals, Inc., 2007). In 2004, 81.5 percent of world refined copper was processed initially through pyrometallurgical circuits, and 18.5 percent was processed through hydrometallurgical circuits.

\section{PYROMETALLURGICAL AND ELECTROREFINING PROCESSES}

Copper sulfides are the chief copper minerals, which are mined and concentrated for pyrometallurgical smelting. Process steps include mining, crushing and grinding, concentration by flotation, pyrometallurgical processing (smelting, converting, and refining), and electrolytic refining (electrorefining) of the smelter product anodes into cathodes of greater than 99.9 percent copper. Figure 4 shows the process flow steps for copper produced by the pyrometallurgical processing route.

To obtain anode copper from pyrometallurgical smelting, one must first mine copper ore. Based upon the productionweighted average operating statistics of a hypothetical world copper smelter in 2002, for every $1 \mathrm{t}$ of anode copper metal produced, $326 \mathrm{t}$ of material is mined, of which $116 \mathrm{t}$ is 


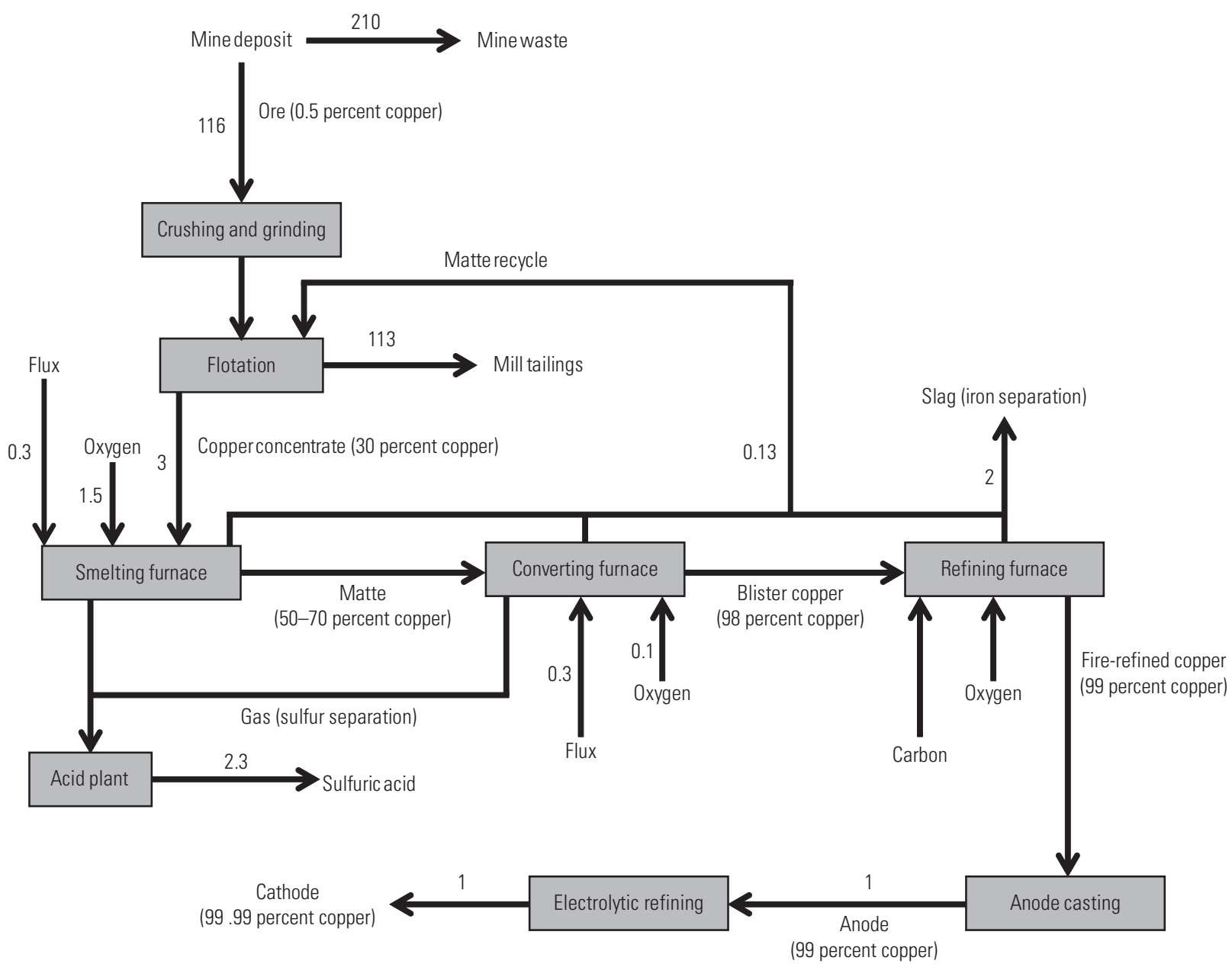

Figure 4. Diagram showing the pyrometallurgical smelting and electrorefining process steps for the production of refined copper. The sources and distribution of U.S. copper supply and scrap recycling are understood to be in terms of "recoverable" copper. Dissipative losses are not identified, though they are understood to exist. Values are in mass units per one mass unit of copper cathode. Source: Goonan, 2004.

useable ore, and $210 \mathrm{t}$ is mine waste. The useable ore, which contains about 0.50 percent copper, then must be crushed, ground, and processed in flotation circuits to produce copper concentrate (containing roughly equal amounts of copper, iron, and sulfur), which is the primary feed for smelting furnaces. For every $1 \mathrm{t}$ of anode copper metal produced, flotation circuits produce $3 \mathrm{t}$ of copper concentrate and $113 \mathrm{t}$ of disposable mill tailings (Goonan, 2004). Pyrometallurgical smelting occurs in suitable furnaces where oxygen and slagmaking fluxes are added to aid the separation of copper metal from iron-containing slag and sulfur-containing gas. The sulfur in the copper concentrate reacts chemically with the oxygen to produce $\mathrm{SO}_{2}$ gas and heat. The iron in the copper concentrate reacts chemically with the oxygen and flux materials to produce a slag (calcium-iron-siliconoxygen), which also releases some heat. The heat release from both reactions is sufficient to melt the reaction product (matte) and fluidize the slag. The slag is tapped from the smelting furnace and often reprocessed through grinding and flotation to recover entrained copper units. The matte, which contains 50 to 70 percent copper, is transferred to a converter furnace to produce blister copper. Oxygen is added to further the separation of copper from the remaining iron and sulfur by means of the same reactions as smelting. The sulfur from both steps leaves the system as a $\mathrm{SO}_{2}$ gas, which is collected and most often processed into sulfuric acid (2.3 t of sulfuric acid per $1 \mathrm{t}$ of copper contained in anodes). A refining furnace (the third step) receives converter copper (about 98 percent copper), oxygen is added to obtain 99 percent copper (complete sulfur removal), and then carbon is added to reduce oxygen in the copper metal. The copper is usually cast into moulds shaped as copper anodes. Smelting and refining together produces $2 \mathrm{t}$ of slag per $1 \mathrm{t}$ of copper contained in anodes (Goonan, 2004). 
The anodes are transported to a different facility for electrolytic refining to obtain 99.99 percent copper cathode. Electrolytic refining cells dissolve copper from a copper anode into the electrolyte and plate copper from the electrolyte to the copper cathode. Trace metals either collect (antimony, bismuth, gold, lead, platinum, selenium, silver, tellurium, and tin) in anode slimes, which drop to the bottom of the cell and are physically removed and further processed, or remain (cobalt, iron, nickel, and zinc) in solution in the electrolyte, thus requiring a bleed stream offtake to remove and recover the residuals and reconstitute the electrolyte (Vlaamse Technische Kring, 2006).

\section{HYDROMETALLURGY AND ELECTROWINNING PROCESSES}

The world copper industry's most widely used and productive hydrometallurgical process for recovering copper directly from ore is solvent-extraction/electrowinning (SX-EW). Figure 5 shows the process flow steps for the SXEW process.
Leaching and SX-EW processing for direct copper cathode production is very effective for recovering copper metal from the oxide ores of copper. These ores occupy the upper reaches of porphyry copper-sulfide deposits, where the sulfide mineralization has been oxidized under near-surface physical conditions. Some ore is mined and placed directly on leach pads, a small amount is leached in situ, but most is crushed to expose more surface area for chemical reaction. Leaching pads are usually lined with high-density polyethylene to prevent losses of valuable copper-bearing solutions and to restrict release of solutions that contain contaminants to the environment. The piles of copper ore (ranging from 0.1 to 1.0 percent copper) being leached are called lifts. A typical leaching lift ranges in height from 30 to 150 meters. The top surface area is frequently more than 15,000 square meters, and the timeframe for leaching to reach optimum completion (about 60 percent copper recovery for the first exposure to leaching fluids $)^{9}$ ranges between 90 and 120 days.

${ }^{9}$ The ultimate copper recovery is greater than 60 percent when residual leaching (multiple exposures to leaching fluids) is considered.

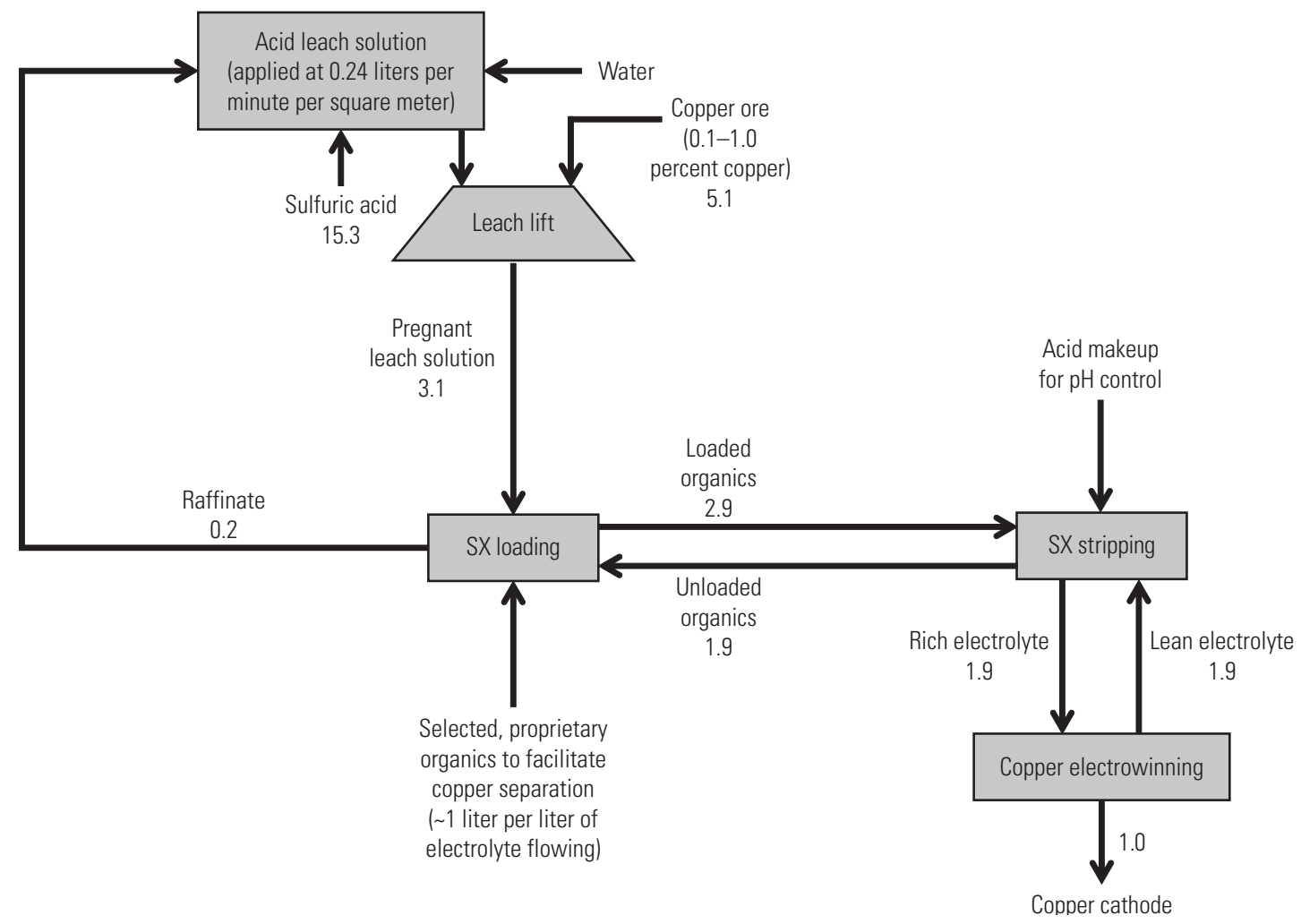

Figure 5. Diagram showing the hydrometallurgical solvent-extraction and electrowinning process steps for the production of refined copper. Except for sulfuric acid, flow values are in mass units of contained copper per one mass unit of copper cathode. The value of sulfuric acid is in mass units for 93-percent sulfuric acid per one mass unit of copper cathode. Lifts are 30 to 150 meters high, greater than 15,000 square meters in top area, and there are 90 to 120 leach days per list. 
The pile is usually preconditioned chemically, based on the chemical makeup of ore and host rock, surface disturbed, and then saturated with a dilute sulfuric acid solution (at a rate of about 0.24 liters per minute per square meter) to dissolve copper into a copper-enriched solution that gravitationally migrates to the bottom of the pile where it collects in a lined pond. The pregnant leach solution (PLS) contains high concentrations of dissolved metals.

The PLS pond is continually tapped for a designed flow into a solvent-extraction facility. There, the PLS is mixed with a combination of organic materials designed (on a facility-specific basis) to preferentially uptake copper. The copper-depleted PLS (raffinate) returns to the leaching area where it is mixed with water and sulfuric acid and is reapplied to the ore on the leach pad. The organics, now loaded with copper, are mixed, in another tank, with $\mathrm{pH}$ adjusted lean electrolyte from the electrowinning process in order to strip copper from the organics. The resulting rich electrolyte flows to the electrowinning cells, and the depleted organics are recycled to the solvent-extraction loading tanks.
The copper is stripped from the electrolyte through electrowinning. Electrowinning is different from electrolytic refining, which is downstream from pyrometallurgical processing. The electrowinning cell has a cathode starter plate and an inert (instead of copper) anode made of a lead alloy. The copper to be collected at the cathode is withdrawn (by chemical reduction of copper ions) from the electrolyte, so the electrolyte needs to be continually replenished with copper ions, which are obtained from the solvent-extraction process.

Hydrometallurgical adaptations and technology advancements have extended the applicability of hydrometallurgy beyond oxide ores (Taylor and Jansen, 2000). Pressure leaching at elevated temperatures in autoclaves and additions of biologic bacterial agents into the process allow hydrometallurgical treatment of sulfide ores and standard sulfide concentrates from flotation mills (Taylor, 2002; Phelps Dodge Corporation, 2007).

\section{SEMIFABRICATION PROCESSES}

Figure 6 is a stylized representation of the processing paths for copper scrap as it is collected and processed to

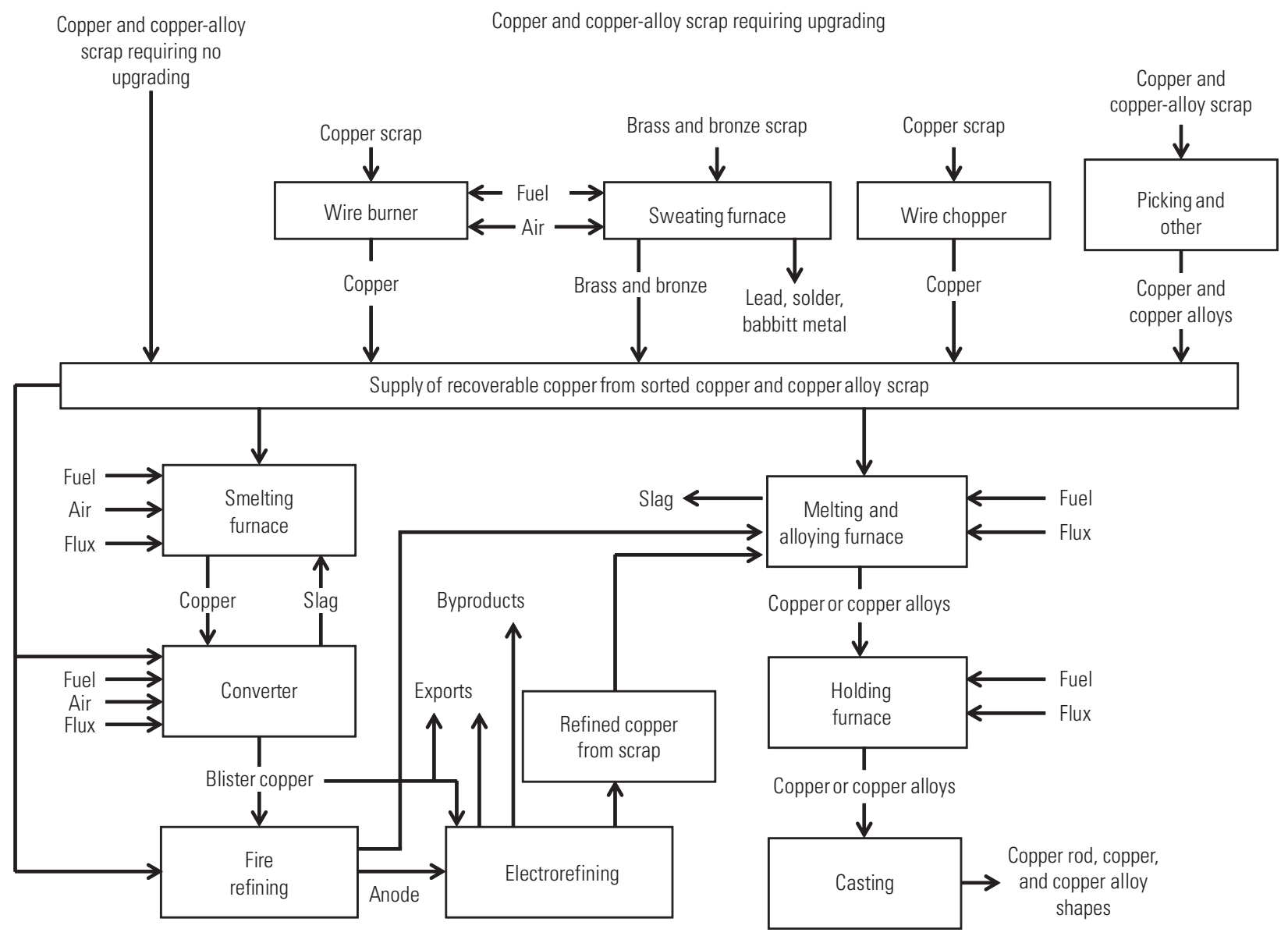

Figure 6. Process flow chart (unquantified) for copper scrap. Adapted from U.S. Environmental Protection Agency, 1995. 
support production of refined copper, copper rod and wire, copper alloys and chemicals, and alloyed castings and shapes.

Before use, copper scrap may or may not require some upgrading in terms of identity and (or) physical character. Processing scrap through picking and sorting processes, sweating furnaces, wire burners, and wire choppers will accomplish the upgrading task. The sum of the product of scrap upgrading and the scrap that does not require any upgrading is the supply of recoverable copper from sorted copper and copper alloys, which is taken by smelters, fire refiners, brass mills, wire rod mills, ingot makers, foundries, and other manufacturers to make copper-bearing products.

Scrap upgrading can be undertaken by scrap-handling specialists or by scrap consumers that have the capability. Typical sources of copper scrap include construction demolition debris, junked automobiles, and electronic scrap collection. Electronic and auto scrap may be processed through shredding and sorting (screening, magnetic, and other) to produce a copper-bearing fraction. Wire goes through a chopping operation ${ }^{10}$ to remove the insulation from the copper, and the copper is ready to proceed to a consumer's melting or alloying furnace. Copper alloy scrap may be passed through a sweating furnace, which provides enough heat to melt and recover lead from solder and babbitt metal. The remaining copper alloy is then ready to be processed directly in a melting or alloying furnace.

At the melting or alloying furnace, the copper, copper alloy, and makeup alloys are blended to make a new alloy to a desired chemical specification. This product is then cast to a desired form. In the case of wire rod production, the melting furnace handles mainly copper and produces rod for further processing to wire in a wire mill. In the case of brass mill and foundry production, the scrap entering the alloying furnace is more likely to be already alloyed. The following section describes some of the furnace types that can participate in the flows pictured in figure 6 .

Types of Furnaces Used in Semifabrication of Copper and Copper Alloy Products.-As described by Jolly (2006, p. 34-36), semifabrication copper production uses various types of scrap melting furnaces, depending on the material being melted. Electric arc furnaces were once popular,but have lost favor, in part because hydrogen absorbed from the air shortened electrode life.

ASARCO Incorporated (Asarco) shaft furnaces are used for melting pure copper cathodes for feed to continuous wire rod casting. Under certain circumstances, limited quantities of high-grade scrap may be added to the melt without previous refining. Asarco shaft furnaces were first built in the 1950s and are manufactured in many sizes. They are shaft furnaces shaped internally like an inverted cone, about one-half as wide at the bottom as at the top. The fuel-to-air mixture, where the fuel can be a variety of gases, is kept slightly reducing.

\footnotetext{
${ }^{10}$ Historically the insulation on wire was burned off.
}

Crucible furnaces are used for a fairly large amount of secondary copper production. They are fired by hydrocarbon gases and oils. They are used for melting clean, well segregated scrap, mostly in foundries. Scrap is usually melted in crucibles by puddling - that is by melting enough to make a liquid puddle, then submerging additional scrap into the melt to become part of the molten material. Such furnaces can be stationary or tilting.

Blast furnaces are used for melting low-grade copper and brass scrap, refinery slags, drosses, and skimmings. In such cases, the material is melted under reducing conditions, and the product is a copper matte and slag. When a furnace is used for melting only scrap, with no chemical reduction required, it is called a cupola. These furnace operations are carried out in a shaft furnace mode with unmelted material charged at the top and countercurrent air forced upwards through the charge. The melted material collects at the bottom and is periodically collected. Oxides of the base metals other than copper dissolve in the slag, fume off, or are reduced and dissolved in the copper melt. The product of the blast furnace is called black copper and may contain any or all of the elements commonly found in copper alloy scrap. Fumed materials are recovered in baghouses and treated for their metal content. A typical product may contain 75 to 88 percent copper, 4 to 10 percent zinc, 1.5 percent tin, 1.5 percent lead, 0.5 to 1.5 percent iron, 0.5 to 1.25 percent sulfur, and 0.1 to 0.7 percent antimony. The calcium-iron-silica slag may also contain up to 1.5 percent copper.

Reverberatory furnaces are box-like refractory-lined structures designed to heat the charge by both conduction and radiation. They are called reverberatory furnaces because the heat from the bath (molten metal plus slag) is radiated (reverberated) from the roof back to the bath. These furnaces can be quite large and are used for melting scrap containing more than 40 percent copper. A few of these types of furnaces are operated by fire refiners associated with tube mills. All the former large-scale reverberatory furnace operations in the United States have been shut down because of the high cost of operation under current pollution control requirements. The closure of reverberatory furnaces has reduced U.S. recycling of low-grade scrap.

Converters, which are part of the stepwise process for producing primary copper, use copper scrap as feed and for cooling and process temperature control. Converters are also used to process the black copper product of blast furnaces. The product of the converter is called blister copper.

Top-blown rotary converters are sometimes used to smelt and refine copper-bearing materials. Some believe that they are more flexible than reverberatory furnaces and can be operated in semicontinuous mode. They can accommodate a wide variety of change materials. These furnaces can meet stringent environmental standards. Capacities run about 45 metric tons per day of alloy.

Low-frequency electric induction furnaces are used by brass mills and ingot makers to melt high-quality scrap and zinc slab in small batches (about $5 \mathrm{t}$ of metal). Melting rates are 
high, and pollution losses are small. These furnaces produce alloys to specification for casting into billets and other shapes.

Sweating is the name given to heating (below the melting point of copper and copper alloys) scrap types that contain low-melting lead alloys, such as borings, lead-sheathed cable, radiators, and auto shredding, which contain valuable lowmelting point metals. Sweating recovers the valuable lead alloys while upgrading the scrap for smelting or direct melt applications. Reverberatory, muffle, and sloping and vibrating hearth-fired furnaces have been used for this purpose.

\section{USES OF COPPER-CONTAINING MATERIALS}

Copper has been useful to humankind for thousands of years because of the metal's attractiveness, conductivity (electrical ${ }^{11}$ and thermal), corrosion resistance, ductility, malleability, and strength. It is readily alloyed with other metals and forms many useful chemicals. Bronze, a family of alloys of copper and tin, has even given its name to a historical timeframe called the "Bronze Age," variously experienced by different cultures within a general time bracket from 3300 through $600 \mathrm{BCE}$; the time period came to be known by this name because tools and weapons were made of bronze rather than the previously used stone (Cowen, 2008).

\section{COPPER END-USE BY ECONOMIC SECTOR}

From 1980 through 2004, the U.S. consumption of copper by sector end-use is shown in figure 7 .

\footnotetext{
${ }^{11}$ Electrical applications account for more than 70 percent of U.S.
} consumption.

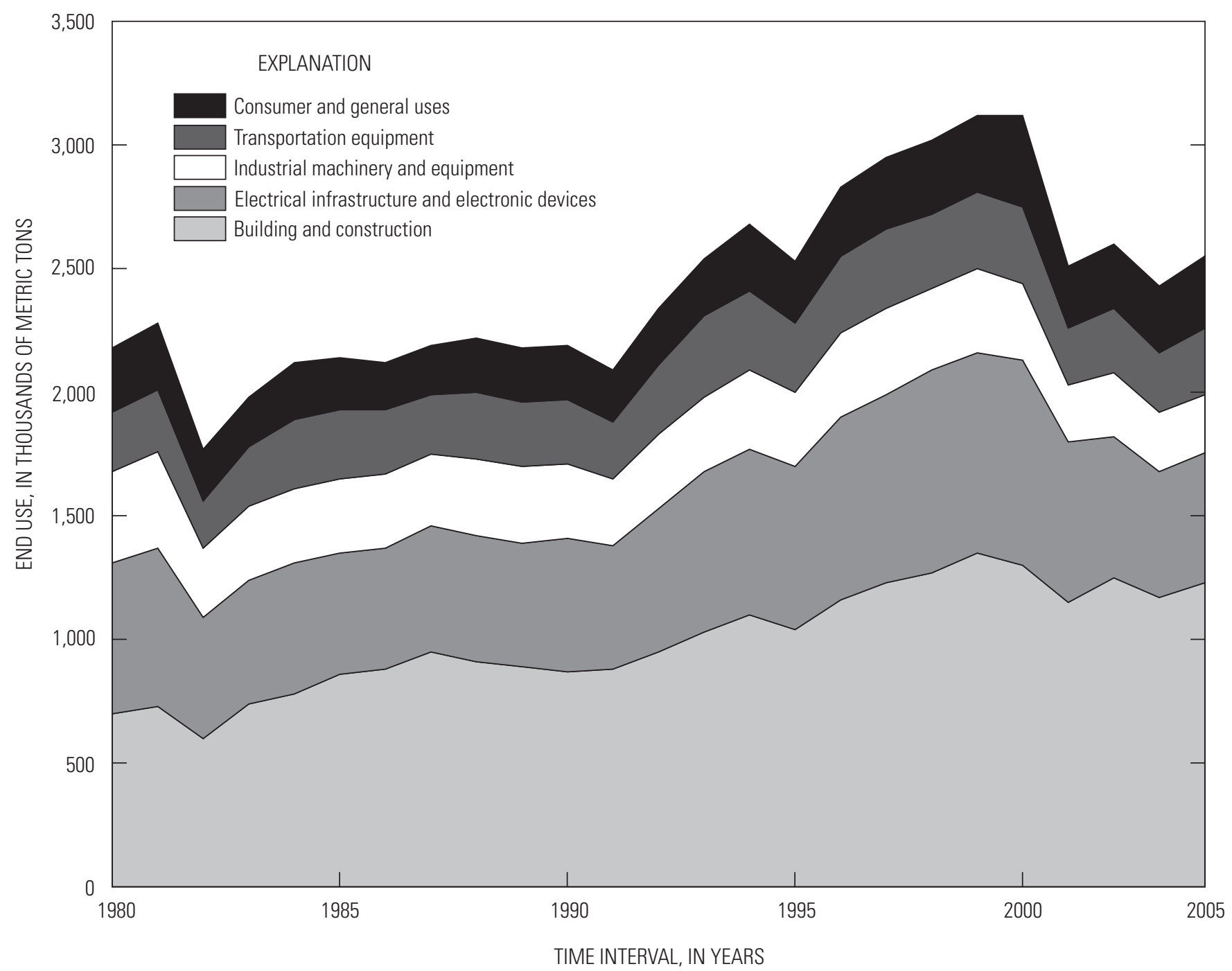

Figure 7. Chart showing U.S. end-use consumption of copper by economic sector from 1980 through 2004 . Values are in metric tons of copper contained. Sources: Copper Development Association Inc., 2005; Kelly and Matos, 2006. 
In 2004, copper consumed by the building and construction sector amounted to 49 percent of the market; correspondingly, electrical and electronic applications comprised 21 percent; industrial machinery and equipment, 9 percent; transportation equipment, 11 percent; and consumer and general use, 11 percent (Edelstein, 2007).

Table 4 lists the annual growth rate trends for various consumer and industrial end-use sectors of the economy for copper contained in semifabricated products for the period from 1980 through 2004.

Table 4. Average annual growth rates for U.S. consumption of copper as contained in semifabricated products from 1980 through 2004, by industrial sector.

[Values are in average annual percentage change. Calculated from original data reported in Copper Development Association Inc., 2005a; and Kelly and Matos, 2006]

\begin{tabular}{lccc}
\hline Economic sector & 1980-1999 & 2000-2004 & 1980-2004 \\
\hline Building and construction ......... & 4.77 & -0.65 & 3.76 \\
Electrical and electronic........... & 2.77 & -7.68 & 1.27 \\
Industrial machinery ................ & 0.00 & -3.93 & -0.61 \\
Transportation equipment ........ & 1.74 & -2.18 & 0.64 \\
Consumer and general............. & 1.50 & -2.90 & 1.52 \\
\hline
\end{tabular}

For the period from 1980 through 1999, all sectors with the exception of industrial machinery experienced average annual growth rates between 2 and 5 percent. Building and construction (5 percent) and electrical and electronics ( 3 percent) showed the most robust growth. For the period from 2000 through 2004, every sector declined with building and construction showing the least decline (1 percent). Electrical and electronics declined by 8 percent, industrial machinery declined by 4 percent, and consumer and general declined by 3 percent.

\section{COPPER END-USE AS ALLOYS AND CHEMICALS}

Copper, whether pure, alloyed, or combined into a chemical formulation, is of great economic importance. In this section, some of the more common copper-bearing products are discussed.

\section{COPPER METAL}

After silver, copper has the highest electrical conductivity (95 percent of the electrical conductivity of silver) among metals. Because silver prices range from 50 to 80 times that of copper, copper is a preferred material for electricity production and distribution in such products as building wire, telecommunications cables, magnet (winding) wire, printed circuit board conductors and a host of other electrical applications. It has sufficient strength, ductility, and hardness for these applications at operating temperatures up to $100^{\circ} \mathrm{C}$ (Callcut, 2006). The addition of alloy elements, while diminishing the electrical properties somewhat, adds strength and higher temperature service, often an acceptable tradeoff. Small (less than 1 percent) additions of phosphorous and tellurium increase the toughness and machineability of copper intended for use as liquid conduits (plumbing pipe and tube) (Anchor Bronze and Metals, Inc., 2007).

\section{COPPER CHEMICALS}

Though they constitute a small percentage of total copper demand, copper chemicals (acetates, chlorides, cyanides, hydroxides, nitrates, oxides, and sulfates) are used as algicides, antifouling agents, disinfectants (for seed), (animal) feed additives, fertilizers, fungicides, inorganic dyes, pesticides, and wood preservatives. Copper chemicals are also used in electroforming, medicines, pharmaceuticals, and photography (Department of Environment and Water Resources, Australia, 2007). By volume, copper sulfate is the most prevalent chemical and is frequently used as feedstock for other copper chemical production. Copper sulfate and oxide can be produced either from primary or scrap materials. In 2004, 12,000 $t$ of copper was contained in copper-bearing chemicals produced from scrap materials in the United States (Edelstein, 2007, table 6).

\section{HIGH-COPPER ALLOYS}

High-copper alloys usually contain more than 94 percent copper. The addition of beryllium ( $0.5-2.0$ percent by weight $)$ to copper produces alloys that exhibit high electrical and thermal conductivity, good corrosion and fatigue resistance, high strength and hardness, and nonmagnetic properties. Copper-beryllium alloys average about 70 percent of annual U.S. consumption on a beryllium metal equivalent basis (Cunningham, 2003). The alloys are used for such applications as bearings, brake drums, electrical connectors, molds, springs, and welding electrodes (Automation Creations, Inc., 2007). In 2004, the U.S. consumption of copper-beryllium alloys accounted for about 5,000 t of copper and $91 \mathrm{t}$ of beryllium contained therein (Shedd, 2008).

The addition of cadmium (0.8-1.2 percent by weight) to copper nearly doubles the mechanical strength and wear resistance of pure copper while retaining 90 percent of its conductivity. Major uses for such alloys include contact wire and catenary strand for railway overhead electrification, electrical components (such as contact strips), special cables for military and aerospace uses, and telephone drop wire (International Cadmium Association, 2007). The United States consumed about $500 \mathrm{t}$ of cadmium in 2004, of which about 0.3 percent was in the form of copper-cadmium alloy (98 percent copper and 1.0 percent cadmium), which computes to about 2,000 t of copper and $1.5 \mathrm{t}$ of cadmium contained in such alloys (Morrow, 2005). 
The addition of chromium (0.6-1.2 percent chromium by weight) nearly doubles the mechanical strength of pure copper, while retaining 85 percent of its conductivity, and improves corrosion resistance (Copper Development Association, 2007a). Major uses for such alloys include resistance welding electrodes, seam welding wheels, switch gears, connectors, circuit breaker parts, molds, spot welding tips, and electrical and thermal conductors that require strength (Copper Development Association, 2007a). Copperchromium alloy consumption data are unavailable; however, the amount of copper associated with copper-chromium alloy consumption is estimated to be on the order of thousands of metric tons.

\section{COPPER-ALUMINUM AND ALUMINUM-COPPER ALLOYS}

The copper content of copper-aluminum alloys ranges from about 70 to 90 percent copper (average copper content is about 85 percent by weight), the balance being aluminum and perhaps small amounts of other elements. Bolts, bushings, cams, and gears made from these materials are corrosion resistant with good strength (Anchor Bronze and Metals, Inc., 2007). In 2004, the United States produced 6,000 t of aluminum bronze materials that contained about 5,000 t of copper (Edelstein, 2007, table 8).

Aluminum bronze is a type of bronze in which aluminum is the main alloying element added to copper. Aluminum bronzes are most valued for their higher strength and corrosion resistance compared with other bronze alloys. They have low oxidation rates at high temperatures and low reactivity to sulfurous compounds and other exhaust products of combustion. They are also resistant to sea water corrosion. Aluminum bronze castings have exceptional corrosion resistance; high strength, toughness, and wear resistance; and good casting and welding characteristics (Copper Development Association, 2008). Aluminum-copper alloys contain copper in the range of 1 to 6 weight percent and do not represent a significant flow of copper.

\section{COPPER-NICKEL AND NICKEL-COPPER ALLOYS}

The copper-nickel alloys include cupronickels (68-88 percent copper and 10-30 percent nickel) and nickel silvers (55-65 percent copper, 12-25 percent nickel, and 3-27 percent zinc) (Anchor Bronze and Metals, Inc., 2007). Because copper-nickel alloys are corrosion and oxidation resistant and thermally stable, they are used in marine and powerplant applications, such as condenser tubes, valves, pumps and fittings (Copper Development Association, 2007b).

Nickel silvers (referring to their luster, not silver content) or nickel brasses have moderately high strength and good corrosion resistance (Copper Development Association, 2007d). They are most often used for housewares and giftware (Smiths Metal Centers, 2006). In 2004, U.S. manufacturers produced 3,000 t (containing about 2,000 $\mathrm{t}$ of copper) of nickel silvers (Edelstein, 2007, table 8; Kuck, 2007, table 4).

Nickel-copper alloys are called monels (30-33 percent copper and 63-65 percent nickel), and these, like cupronickels, are used largely in marine applications where the properties sought are resistance to biofouling, corrosion, and erosion (Greetham, 2003). In 2004, U.S. manufacturers produced $27,000 \mathrm{t}$ (containing about 19,000 t of copper) of cupronickel alloys (Kuck, 2007, table 4).

\section{COPPER-TIN ALLOYS}

The copper-tin alloys or tin bronzes (70-90 percent copper, 5-12 percent tin, balance other metal) have good corrosion resistance and are stronger and more ductile than brass. Additions of lead (6-12 percent) diminish alloy strength but enhance machineability (Copper Development Association, 2007c).

Bronze alloys (22-24 weight percent copper) are used for making bells, cymbals, and cast metal sculpture (Bhadeshia, 2005). When struck against a hard surface, bronze will not generate sparks. Bronze hammers, mallets, wrenches, and other durable tools can be used in explosive atmospheres or in the presence of flammable vapors (Canadian Centre for Occupational Health and Safety, 1999). In 2004, 36,000 t (containing about 29,000 t of copper, 3,000 t of tin, and 4,000 $t$ of other metals) of copper-tin alloys was produced in the United States (Carlin, 2006).

\section{COPPER-ZINC ALLOYS}

Copper-zinc alloys normally, though not always, called brasses include between 10 and 40 percent zinc and often other elements (lead, tin, other) to provide special characteristics. The average copper content of copper-zinc alloys is about 73 percent.

Brass is used in decorative and artistic applications, hardware, munitions, and plumbing. Leaded brasses contain from 0.5 to 3 percent lead and are used as pump cylinder liners, plumbing accessories, gears, and pinions because the addition of lead improves the alloy's machineability (Anchor Bronze and Metals, Inc., 2007). In 2004, 322,000 t of brass (containing about 226,000 t of copper and 97,000 t of zinc) was produced by U.S. brass producers (Jorgenson, 2007).

\section{PRICES}

Copper metal (99.99 percent pure cathode) is traded on the London Metal Exchange (LME), the New York Merchantile Exchange's COMEX Division (COMEX), and the Shanghai Commodity Exchange. Prices established by the exchanges are the basis for most physical transactions, with producers and merchants adding a premium to the 
exchange price to cover shipping and storage costs and profit. Prices on the COMEX and LME track closely (usually not varying more than 5 cents per pound on any given day), the differences being attributable to local market conditions and changes in currency exchange rates. Copper scrap is not traded on these exchanges. However, scrap prices are negotiated as either a discount from or premium addition to the price of refined copper as determined by the commodity exchanges (Burghardt, 2004).

There are many factors that determine copper scrap prices including local supply and demand for a particular type of scrap. conversion costs, transportation costs, and current prices for the metals contained in the scrap (copper, zinc, other). Competition for domestic copper scrap from Chinese companies has shrunk scrap discounts below what they might have been, prior to their entry into the market, for material delivered to U.S. brass mills and others, thereby increasing their relative raw material costs (Burghardt, 2004).
Figure 8 shows market price indices ${ }^{12}$ for primary copper metal and its major alloying elements (aluminum, lead, nickel, tin, and zinc) for the period from 1954 through 2007. The base year for the price indices is 1991. Temporal datasets are of interest for context and projection. In this particular temporal dataset, prices (in terms of indices) fall into three fairly distinct regions in figure 8. For the period from 1954 through 1973, the prices for all metals are relatively stable (flat line) with low volatility (little variance). The index averages (which reflect price level compared with the average price during the base year) plus or minus $( \pm)$ a standard deviation (which reflects price volatility) for the 1954-73

\footnotetext{
${ }^{12}$ The index for the commodity is defined as the nominal annual average price for the commodity in a given year divided by the nominal annual average price for the commodity in 1991. The base year 1991 was selected because it was a year where volatility (variability around the average) for most of the selected commodities was low. The reason for constructing a price index, rather than just plotting prices, was to represent all commodities at the same scale to facilitate comparison.
}

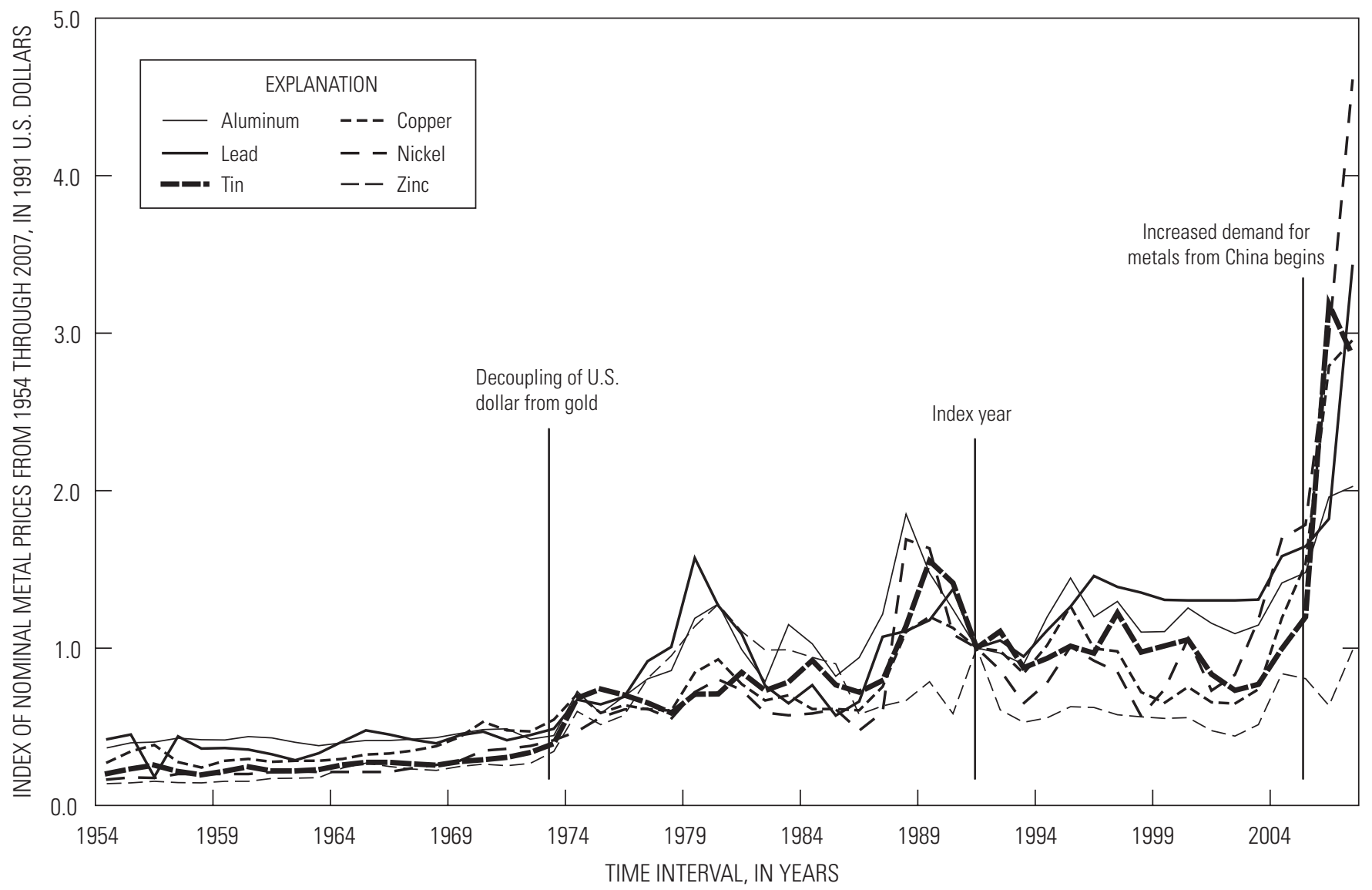

Figure 8. Chart showing indexed prices for copper and its major alloying elements from 1954 through 2007. Base year is 1991. Values represent the index of the selected commodity's nominal price for the year in question divided by its price in 1991. The values for copper metal prices are in dollars per kilogram metal as reported by the COMEX Division of the New York Mercantile Exchange. Sources: U.S. Geological Survey, 1999, 2004, 2005, 2006. 
period for each element were aluminum, $0.42 \pm 0.03$; copper, $0.36 \pm 0.09$; lead, $0.40 \pm 0.05$; nickel, $0.25 \pm 0.07$; tin, 0.21 \pm 0.06 ; and zinc, $0.26 \pm 0.05$.

In 1973, the dollar was decoupled from gold. The result was an increase in the price levels and the price volatility for the metals in question. For the period from 1974 through 2004, the index averages \pm standard deviation for the elements were aluminum, $1.11 \pm 0.27$ (a price level increase of 160 percent and a volatility increase of 870 percent); copper, $0.84 \pm 0.24$ (a price level increase of 136 percent and a volatility increase of 161 percent); lead, $1.11 \pm 0.31$ (a price level increase of 179 percent and a volatility increase of 302 percent); nickel, $0.86 \pm 0.37$ (a price level increase of 247 percent and a volatility increase of 410 percent); tin, $0.73 \pm 0.22$ (a price level increase of 246 percent and a volatility increase of 283 percent); and zinc, $0.91 \pm 0.22$ (a price level increase of 249 percent and a volatility increase of 375 percent).

After 2004, China became a heavy user of these elements, and figure 8 shows the resulting price increases from the previous period's averages. These Chinese demand-driven prices may or may not be sustainable in the long run. Since
January 1, 2006, nominal prices for nickel rose to peak in May 2007 at four times the price in January 2006, followed by a decline by August 2008 to 40 percent more than the January 2006 price. The nominal price for copper, on the other hand, has held steady at roughly 60 percent higher than the January 2006 level for the period from May 2006 through August 2008.

"No. 1 heavy and wire" copper scrap is an unalloyed copper scrap. "Automobile radiators (unsweated)" is a medium quality brass scrap. Figure 9 compares monthly dealer prices for these two copper scrap types with COMEX copper metal prices for the period from January 1997 through February 2007.

Copper scrap has historically closely followed copper metal prices. Based on the data underlying figure 9, for the period from January 1997 through September 2003, the ratio of the price for "No. 1 heavy and wire" copper scrap to the price for copper metal averaged $0.73 \pm 0.07$ (one standard deviation); the ratio of the price for "automobile radiators (unsweated)" copper scrap to the price of copper metal averaged 0.41 \pm 0.03 on a copper-content basis and $0.59 \pm 0.05$ on a copperequivalent basis. On the basis of contained copper, the two

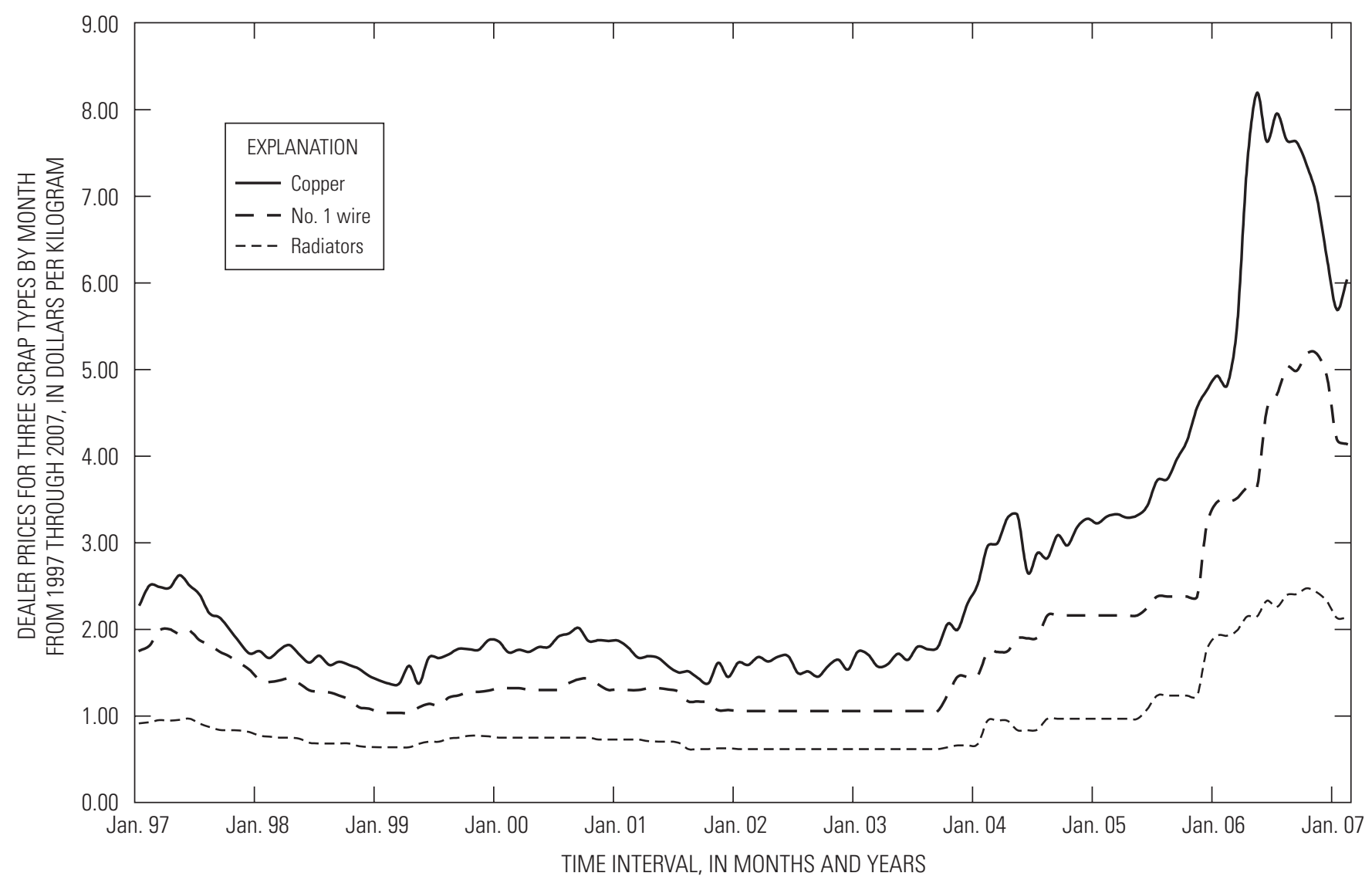

Figure 9. Chart showing monthly dealer prices of "no. 1 heavy and wire," "automobile radiators (unsweated)," and copper metal from 1997 through 2007. The values for scrap prices are dealer purchasing prices in dollars per kilogram at Chicago, Ill. The values for copper metal prices are in dollars per kilogram metal as reported by the Commodity Exchange, Inc. division of the New York Mercantile Exchange. Sources: American Metal Market, 2007; Futures Trading Charts, 2007. 
scrap classes are discounted from high-grade refined copper, on average, by 27 and 41 percent respectively.

From October 2003 through February 2007, prices for all copper metal and alloys have increased markedly. During this period of increasing prices, the relative ratios have also changed. The new ratio of "No. 1 heavy and wire" copper scrap price to copper metal price averaged $0.66 \pm 0.07$, and the new ratio of "automobile radiators (unsweated)" copper scrap price to copper metal price averaged $0.32 \pm 0.03$.

The Institute of Scrap Recycling Industries, Inc. (ISRI) recognizes about 53 classes of copper and copper alloy scrap (Jolly, 2006, p. 19). Table 5 lists some of the more significant ISRI copper scrap classifications and their most likely recycling user.

Dealer prices are paid to those delivering scrap to the dealer's scrap yard. Consumer prices are those paid by purchasers of processed scrap. Copper scrap prices vary by grade and with local conditions.

\section{SOURCES AND DISPOSITION OF COPPER SCRAP}

There are two conditions necessary for recycling to occur. First, there must be a supply of material. Many materials dissipate with use and cannot be recycled (for example, fertilizer). While small amounts of copper are dissipated in use, the vast majority of the mass of copper placed in service is conserved, losing only its economic utility with use. These copper sources are candidates for recycling, and there is a ready supply. Second, the cost of identifying, collecting, processing, and transporting scrap materials must be low enough to provide a profit margin for the entity performing that task to do so. Metals are relatively scarce and thus generally have prices high enough to cover the recycler's costs and provide the recycler's required margin. During periods of low prices, margins decrease, and the cost of collection for certain scrap types may become prohibitive, which leads to

Table 5. Copper scrap classifications and most likely users.

[Values are denominated in column headings. NA, not available. Source: Jolly, 2006, p. 20-21, 69]

\begin{tabular}{|c|c|c|c|}
\hline ISRI scrap type & $\begin{array}{c}\text { Copper } \\
\text { content, } \\
\text { in percent }\end{array}$ & Other metal content, in percent & Priority users \\
\hline \multicolumn{4}{|c|}{ Unalloyed copper scrap } \\
\hline 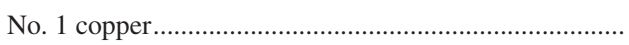 & 99.5 & & Brass and wire rod mills. \\
\hline 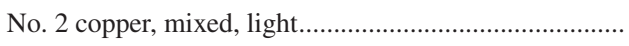 & 96.8 & & Fire refiners, ingot makers. \\
\hline Other . & 96.5 & & NA. \\
\hline \multicolumn{4}{|c|}{ Copper-base alloy scrap } \\
\hline High coppers: beryllium, cadmium, or chromium........... & 96.4 & Nickel or cobalt, 1.5 ; other, 1.4 & \\
\hline Red brass & 92.5 & Lead, 1.45; zinc, 7.0 & Ingot makers and foundries. \\
\hline 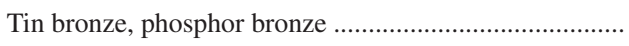 & 82.1 & Tin, 13.0; zinc, 2.6; nickel or cobalt, 1.3 & Foundries. \\
\hline 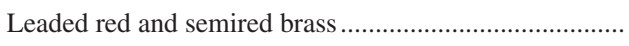 & 80.5 & Tin, 4.0; lead, 5.3; zinc, 10.5 & Foundries. \\
\hline 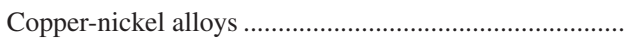 & 80.1 & Nickel or cobalt, 17.5 ; manganese, 1.5 & Foundries. \\
\hline Silicon bronze and brass ......... & 78.5 & Zinc, 18; manganese, 0.75 & Foundries. \\
\hline 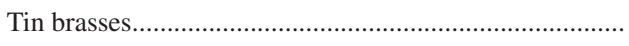 & 72.5 & Tin, 2.1; lead, 1.3; zinc, 23.2 & Brass mills. \\
\hline High leaded tin bronzes & 68.5 & Tin, 7.8; lead, 20.5; zinc, 2.0 & Brass mills. \\
\hline 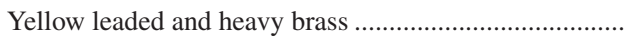 & 66.0 & Tin, 1.4; lead, 2.6; zinc, 30.5 & Brass mills. \\
\hline Yellow and low brass, and other copper-zinc brasses..... & 73.8 & Zinc, 24.5; aluminum, 4.0 & Brass mills, foundries. \\
\hline 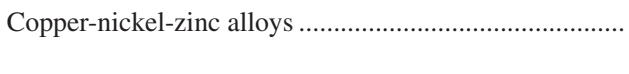 & 57.8 & $\begin{array}{l}\text { Tin, } 3.5 \text {; lead, } 5.6 \text {; zinc, } 13 \text {; nickel or cobalt, } \\
\text { 15.5; manganese, } 1.5\end{array}$ & Foundries. \\
\hline Manganese bronze ............... & 51.8 & $\begin{array}{l}\text { Tin, } 1.0 ; \text { zinc, } 32.0 ; \text { aluminum, } 4.0 ; \text { nickel or } \\
\text { cobalt, } 2.0 ; \text { manganese, } 2.5\end{array}$ & Foundries. \\
\hline Aluminum bronze .................. & 79.5 & $\begin{array}{l}\text { Aluminum, } 9.75 \text {; nickel or cobalt, } 2.8 \text {; manga- } \\
\text { nese, } 7.0 \text {; other, } 2.5\end{array}$ & Foundries. \\
\hline \multicolumn{4}{|c|}{ Common scrap groups } \\
\hline Water meters & 63.5 & Lead, 1.2; zinc, 34.7 & Foundries. \\
\hline Auto radiators (ocean) & 69.0 & Tin, 4.0; lead, 9.5; zinc, 12.5 & Foundries. \\
\hline Cocks and faucets (grape) & 59.0 & Tin, 1.0; lead, 4.0; zinc, 24.0 & Foundries. \\
\hline 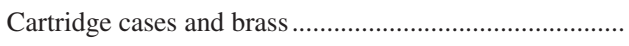 & 70.0 & Zinc, 29.9 & Brass mills. \\
\hline 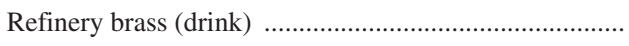 & 61.3 & Other, 39.0 & Brass mills, ingot makers, and foundries. \\
\hline 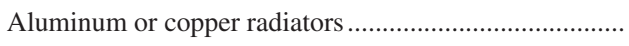 & 45.6 & Aluminum, 54.0 & Foundries and brass mills. \\
\hline Copper-bearing material & 40.0 & Other, 60.0 & Ingot makers and chemical plants. \\
\hline
\end{tabular}


declines in the recovery of copper from scrap. When scrap prices are high enough to cover the cost of recycling and provide a suitable profit, one can expect copper recovery from scrap to increase. In some instances, disposal costs may serve as a credit to the value of recovered metal and provide additional margin or incentive for recovery. Recycling can be increased if subsidized through policy.

This section examines the sources and distribution of recyclable copper scrap, both new and old.

Figure 10 shows sources and distribution of new and old scrap in the United States in 2004. It was assumed that old scrap supplied the export market and that new scrap was returned to U.S. smelters and first-use consumers (if not entirely, then almost so).

In 2004, 1.92 Mt of copper was contained in old scrap derived from the U.S. product reservoir based on estimates of loss of utility for sectors within the reservoir, and 735,000 t of copper was contained in new scrap. Of the copper contained in new scrap, 95 percent was generated by manufacturers using semifabricated products, and 5 percent was generated from semifabrication processing by brass, wire rod and wire mills, ingot makers, foundries, and others. The 735,000 t of copper contained in new scrap was returned (recycled) to U.S. semifabricated product producers (97 percent), refined copper producers ( 2 percent), and noncopper producers ( 1 percent). Of the old scrap generated, $1.15 \mathrm{Mt}$ of copper (60 percent) was unrecovered (left in place pending more favorable economic conditions, or landfilled), and 772,000 t (40 percent) was recovered. The copper contained in recovered old scrap was augmented by $80,000 \mathrm{t}$ of copper contained in scrap imports and 3,000 t of copper contained in stock drawdown, to provide a total of $855,000 \mathrm{t}$ of copper contained in old scrap processed. This supply of old scrap to be processed was distributed as 74 percent for exports, 20 percent for U.S. copper processors, and 6 percent for noncopper producers. U.S. copper processors received 895,000 t of copper as scrap, 81 percent of which was new scrap, and 19 percent was old scrap. Semifabricators received 94 percent of the total, of which 84 percent was new scrap and 16 percent was old scrap. Primary refined copper producers received 6 percent of the total, of which 31 percent was new scrap and 69 percent was old scrap.

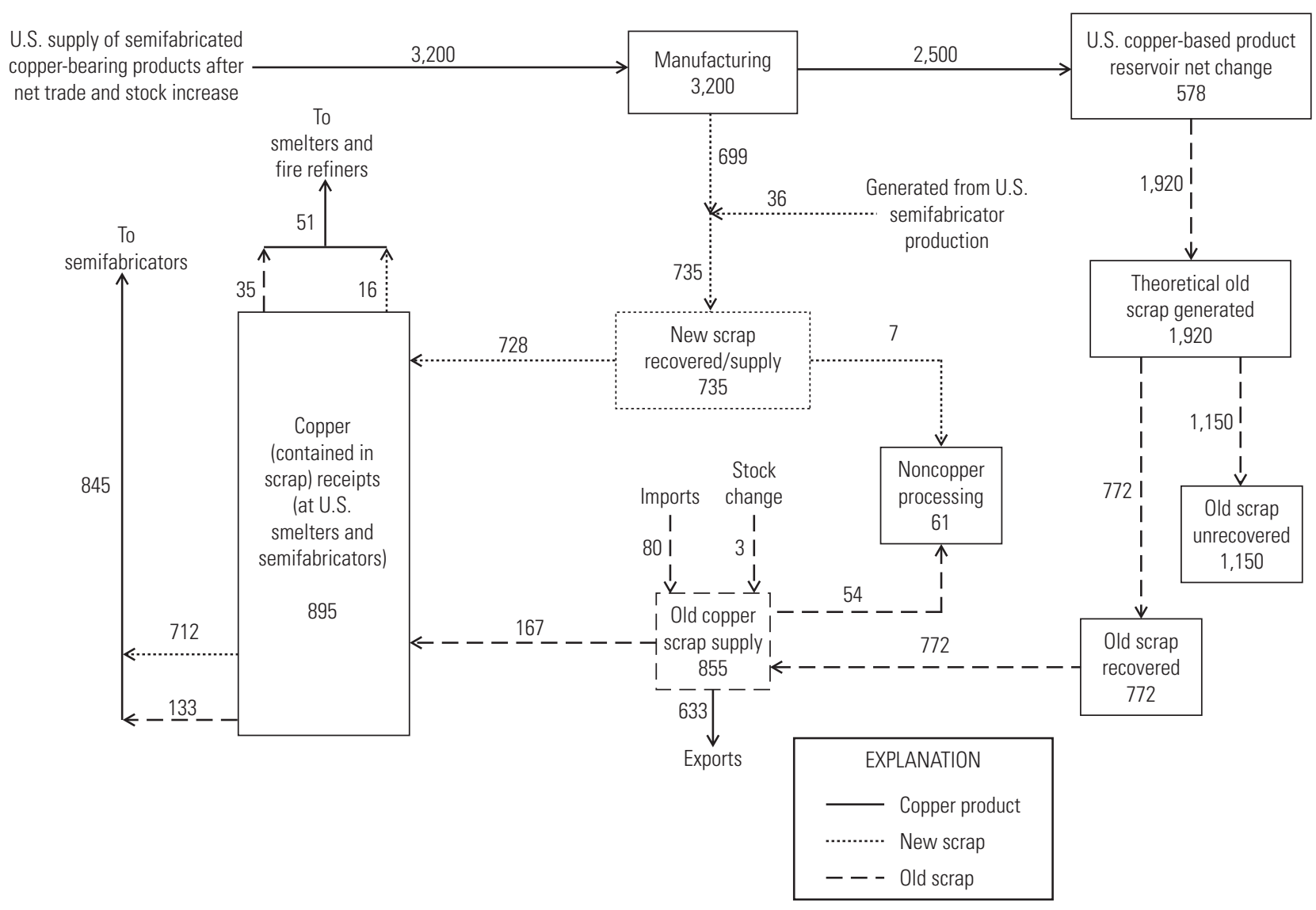

Figure 10. Diagram showing copper scrap generation and flow in the United States in 2004. Values are rounded to the nearest thousand metric ton of contained copper. The sum of the parts may not equal the totals shown owing to independent rounding. Sources: International Copper Study Group, 2005a, b; Jolly, 2006; Kelly and Matos, 2006; Baker, 2007; Edelstein, 2007. 


\section{OLD SCRAP}

Old scrap recycling efficiency shows the relation between what is theoretically available for recycling and what was actually recovered, and recycling rate is that fraction of apparent metal supply that is derived from scrap. In 2004, the domestic old scrap recycling efficiency for copper was estimated to be 43 percent of theoretical old scrap supply, and the recycling rate was 30 percent of apparent copper supply.

\section{OLD SCRAP GENERATED}

The USGS estimated that, in 2004, $1.92 \mathrm{Mt}$ of copper contained in old scrap was generated as end-of-life material from the U.S. copper products in-service reservoir. The development of the estimate is shown in table 6, which considers the distribution of copper to defined economic sectors with annual variance included, the average life of products within sectors, and an assumption (in conformance to common practice) of Gaussian decay of economic utility of the scrap.
In table 6, the method for estimating old scrap generated is shown completely for the sector building and construction, and only the results are reported for the remaining sectors. The historic sector consumption data ${ }^{13}$ are from Kelly and Matos (2006), and the average life estimates for the sectors are from the report of the International Copper Study Group (2005a).

Most of the material from building and construction that loses economic utility, and therefore theoretically becomes available after an average 40-year life (averaged from data provided in International Copper Study Group, 2005a, p. 17-18), is derived from construction that consumed those materials about 40 years ago; the amount of old scrap generated decreases more and more as the year of consumption deviates from the 40-year lifecycle. In $2004,563,000 \mathrm{t}$ of copper

\footnotetext{
${ }^{13}$ The data set published by Kelly and Matos (2006) covers the period 1975 through 2004. To apply the Gaussian distribution for a longer lifetime and a larger spread, it was necessary to extrapolate the USGS data set to earlier years by application of selected sector participation fractions to total reported apparent consumption for those earlier years.
}

Table 6. The development of the estimate for old scrap generated in 2004 .

[Consumption and old scrap generated are in metric tons of copper. The information in row "2004" is old scrap generated through 2003 and available for use in 2004, by sector, with the total at the lower far right corner of the table. - , zero; NA, not available. Sources: International Copper Study Group, 2005a; Jolly, 2006; Kelly and Matos, 2006]

\begin{tabular}{|c|c|c|c|c|c|c|c|c|c|}
\hline \multirow{2}{*}{ Year } & \multirow{2}{*}{$\begin{array}{l}\text { Product } \\
\text { life, } \\
\text { in years }\end{array}$} & \multicolumn{3}{|c|}{ Building and construction } & \multirow{2}{*}{$\begin{array}{l}\text { Electrical and } \\
\text { electronic } \\
\text { products, } \\
\text { old scrap } \\
\text { generated }\end{array}$} & \multirow{2}{*}{$\begin{array}{l}\text { Industrial } \\
\text { machinery and } \\
\text { equipment, } \\
\text { old scrap } \\
\text { generated }\end{array}$} & \multirow{2}{*}{$\begin{array}{l}\text { Transportation } \\
\text { equipment, old } \\
\text { scrap generated }\end{array}$} & \multirow{2}{*}{$\begin{array}{l}\text { Consumer and } \\
\text { general } \\
\text { products, } \\
\text { old scrap } \\
\text { generated }\end{array}$} & \multirow{2}{*}{$\begin{array}{c}\text { Old scrap } \\
\text { generated } \\
\text { through } 2003 \\
\text { and available } \\
\text { in } 2004\end{array}$} \\
\hline & & Consumption & $\begin{array}{l}\text { Gaussian } \\
\text { distribution }\end{array}$ & $\begin{array}{l}\text { Old scrap } \\
\text { generated }\end{array}$ & & & & & \\
\hline $1928 \ldots \ldots$ & 76 & 300,000 & 0.0000 & 3 & - & - & - & - & 3 \\
\hline $1929 \ldots \ldots$ & 75 & 310,000 & 0.0000 & 5 & - & - & - & - & 8 \\
\hline $1930 \ldots \ldots$ & 74 & 350,000 & 0.0000 & 8 & - & - & - & - & 16 \\
\hline $1931 \ldots \ldots$ & 73 & 330,000 & 0.0000 & 12 & - & - & - & - & 28 \\
\hline $1932 \ldots \ldots$ & 72 & 370,000 & 0.0001 & 21 & - & - & - & - & $\begin{array}{l}20 \\
49\end{array}$ \\
\hline $1933 \ldots \ldots$ & 71 & 400,000 & 0.0001 & 35 & - & - & - & - & 84 \\
\hline $1934 \ldots \ldots$ & 70 & 310,000 & 0.0001 & 39 & - & - & - & - & 123 \\
\hline $1935 \ldots \ldots$ & 69 & 230,000 & 0.0002 & 42 & - & - & - & - & 165 \\
\hline $1936 \ldots \ldots$ & 68 & 140,000 & 0.0003 & 38 & - & - & - & - & 203 \\
\hline $1937 \ldots \ldots$ & 67 & 180,000 & 0.0004 & 72 & - & - & - & - & 275 \\
\hline $1938 \ldots \ldots$ & 66 & 140,000 & 0.0006 & 75 & - & - & - & - & 350 \\
\hline $1939 \ldots \ldots$ & 65 & 250,000 & 0.0008 & 193 & - & - & - & - & 543 \\
\hline $1940 \ldots \ldots$ & 64 & 330,000 & 0.0011 & 354 & - & - & - & - & 897 \\
\hline $1941 \ldots \ldots$ & 63 & 330,000 & 0.0014 & 483 & - & - & - & - & 1,380 \\
\hline $1942 \ldots \ldots$ & 62 & 210,000 & 0.0019 & 416 & - & - & - & - & 1,800 \\
\hline $1943 \ldots \ldots$ & 61 & 320,000 & 0.0026 & 818 & - & - & - & - & 2,610 \\
\hline $1944 \ldots \ldots$ & 60 & 420,000 & 0.0034 & 1,403 & - & - & - & - & 4,020 \\
\hline $1945 \ldots \ldots$ & 59 & 660,000 & 0.0043 & 2,852 & - & - & - & - & 6,870 \\
\hline $1946 \ldots \ldots$ & 58 & 590,000 & 0.0055 & 3,244 & - & - & - & - & 10,100 \\
\hline $1947 \ldots \ldots$ & 57 & 590,000 & 0.0069 & 4,054 & - & - & - & - & 14,200 \\
\hline $1948 \ldots \ldots$ & 56 & 580,000 & 0.0086 & 5,000 & - & - & - & - & 19,200 \\
\hline $1949 \ldots \ldots$ & 55 & 550,000 & 0.0105 & 5,806 & - & - & - & - & 25,000 \\
\hline $1950 \ldots \ldots$ & 54 & 570,000 & 0.0127 & 7,271 & - & - & - & - & 32,200 \\
\hline $1951 \ldots \ldots$ & 53 & 540,000 & 0.0152 & 8,166 & - & - & - & - & 40,400 \\
\hline $1952 \ldots \ldots$ & 52 & 540,000 & 0.0178 & 9,614 & - & - & - & - & 50,000 \\
\hline
\end{tabular}


Table 6. The development of the estimate for old scrap generated in 2004-Continued.

[Consumption and old scrap generated are in metric tons of copper. The information in row "2004" is old scrap generated through 2003 and available for use in 2004, by sector, with the total at the lower far right corner of the table. —, zero ; NA, not available. Sources: International Copper Study Group, 2005a; Jolly, 2006; Kelly and Matos, 2006]

\begin{tabular}{|c|c|c|c|c|c|c|c|c|c|}
\hline \multirow[b]{2}{*}{ Year } & \multirow{2}{*}{$\begin{array}{l}\text { Product } \\
\text { life, } \\
\text { in years }\end{array}$} & \multicolumn{3}{|c|}{ Building and construction } & \multirow{2}{*}{$\begin{array}{l}\text { Electrical and } \\
\text { electronic } \\
\text { products, } \\
\text { old scrap } \\
\text { generated }\end{array}$} & \multirow{2}{*}{$\begin{array}{l}\text { Industrial } \\
\text { machinery and } \\
\text { equipment, } \\
\text { old scrap } \\
\text { generated }\end{array}$} & \multirow{2}{*}{$\begin{array}{l}\text { Transportation } \\
\text { equipment, old } \\
\text { scrap generated }\end{array}$} & \multirow{2}{*}{$\begin{array}{l}\text { Consumer and } \\
\text { general } \\
\text { products, } \\
\text { old scrap } \\
\text { generated }\end{array}$} & \multirow{2}{*}{$\begin{array}{c}\text { Old scrap } \\
\text { generated } \\
\text { through } 2003 \\
\text { and available } \\
\text { in } 2004\end{array}$} \\
\hline & & Consumption & $\begin{array}{c}\text { Gaussian } \\
\text { distribution }\end{array}$ & $\begin{array}{l}\text { Old scrap } \\
\text { generated }\end{array}$ & & & & & \\
\hline $1953 \ldots \ldots$. & 51 & 440,000 & 0.0207 & 9,230 & - & - & - & - & 59,300 \\
\hline $1954 \ldots \ldots$ & 50 & 450,000 & 0.0238 & 10,666 & - & - & - & - & 69,900 \\
\hline $1955 \ldots \ldots$ & 49 & 520,000 & 0.0269 & 13,967 & - & - & - & - & 83,900 \\
\hline $1956 \ldots \ldots$ & 48 & 540,000 & 0.0301 & 16,312 & - & - & - & - & 100,000 \\
\hline $1957 \ldots \ldots$ & 47 & 520,000 & 0.0332 & 17,325 & - & - & - & - & 118,000 \\
\hline $1958 \ldots \ldots$ & 46 & 440,000 & 0.0361 & 15,958 & - & - & - & - & 133,000 \\
\hline $1959 \ldots \ldots$ & 45 & 550,000 & 0.0388 & 21,174 & - & - & - & - & 155,000 \\
\hline $1960 \ldots \ldots$ & 44 & 550,000 & 0.0412 & 22,593 & - & - & - & - & 177,000 \\
\hline $1961 \ldots \ldots$ & 43 & 490,000 & 0.0431 & 20,910 & - & - & - & - & 198,000 \\
\hline $1962 \ldots \ldots$ & 42 & 440,000 & 0.0445 & 19,518 & - & - & - & - & 218,000 \\
\hline $1963 \ldots \ldots$ & 41 & 520,000 & 0.0454 & 23,551 & - & - & - & - & 241,000 \\
\hline $1964 \ldots \ldots$ & 40 & 490,000 & 0.0457 & 22,176 & - & - & - & - & 263,000 \\
\hline $1965 \ldots \ldots$ & 39 & 510,000 & 0.0454 & 23,095 & - & - & - & - & 286,000 \\
\hline $1966 \ldots \ldots$ & 38 & 550,000 & 0.0445 & 24,435 & - & - & - & - & 311,000 \\
\hline $1967 \ldots \ldots$ & 37 & 570,000 & 0.0431 & 24,659 & - & - & - & - & 336,000 \\
\hline $1968 \ldots \ldots$ & 36 & 600,000 & 0.0412 & 24,522 & - & - & - & - & 360,000 \\
\hline $1969 \ldots \ldots$ & 35 & 660,000 & 0.0388 & 25,720 & 6 & 4 & 3 & - & 386,000 \\
\hline $1970 \ldots \ldots$ & 34 & 740,000 & 0.0361 & 26,839 & 20 & 12 & 9 & - & 413,000 \\
\hline $1971 \ldots \ldots$ & 33 & 620,000 & 0.0332 & 20,434 & 44 & 26 & 19 & - & 433,000 \\
\hline $1972 \ldots \ldots$ & 32 & 640,000 & 0.0301 & 19,232 & 114 & 68 & 48 & - & 453,000 \\
\hline $1973 \ldots \ldots$ & 31 & 690,000 & 0.0269 & 18,563 & 285 & 170 & 121 & - & 472,000 \\
\hline $1974 \ldots \ldots$ & 30 & 610,000 & 0.0238 & 14,486 & 550 & 328 & 234 & - & 487,000 \\
\hline $1975 \ldots \ldots$ & 29 & 470,000 & 0.0207 & 9,749 & 798 & 570 & 433 & - & 499,000 \\
\hline $1976 \ldots \ldots$ & 28 & 610,000 & 0.0178 & 10,888 & 2,109 & 1,362 & 1,274 & - & 515,000 \\
\hline $1977 \ldots \ldots$ & 27 & 660,000 & 0.0152 & 10,006 & 4,296 & 2,625 & 2,307 & - & 534,000 \\
\hline $1978 \ldots \ldots$ & 26 & 780,000 & 0.0127 & 9,914 & 8,391 & 5,143 & 4,195 & - & 562,000 \\
\hline $1989 \ldots \ldots$ & 25 & 780,000 & 0.0105 & 8,204 & 14,274 & 8,434 & 6,920 & - & 599,000 \\
\hline $1980 \ldots \ldots$ & 24 & 700,000 & 0.0086 & 6,013 & 19,804 & 12,012 & 7,792 & - & 645,000 \\
\hline $1981 \ldots \ldots$ & 23 & 730,000 & 0.0069 & 5,055 & 29,301 & 17,856 & 11,446 & - & 709,000 \\
\hline $1982 \ldots \ldots$ & 22 & 600,000 & 0.0055 & 3,306 & 29,720 & 16,983 & 11,524 & - & 770,000 \\
\hline $1983 \ldots \ldots$ & 21 & 740,000 & 0.0043 & 3,202 & 37,742 & 22,645 & 18,116 & 2 & 852,000 \\
\hline $1984 \ldots \ldots$ & 20 & 780,000 & 0.0034 & 2,616 & 46,772 & 26,475 & 24,710 & 12 & 952,000 \\
\hline $1985 \ldots \ldots$ & 19 & 860,000 & 0.0026 & 2,207 & 47,492 & 29,077 & 27,139 & 52 & $1,060,000$ \\
\hline $1986 \ldots \ldots$ & 18 & 880,000 & 0.0019 & 1,705 & 49,000 & 30,000 & 26,000 & 182 & $1,170,000$ \\
\hline $1987 \ldots \ldots$ & 17 & 950,000 & 0.0014 & 1,372 & 49,431 & 28,108 & 23,262 & 635 & $1,270,000$ \\
\hline $1988 \ldots \ldots$ & 16 & 910,000 & 0.0011 & 967 & 45,007 & 27,357 & 23,827 & 1,976 & $1,370,000$ \\
\hline $1989 \ldots \ldots$ & 15 & 890,000 & 0.0008 & 687 & 37,742 & 23,400 & 19,626 & 4,764 & $1,450,000$ \\
\hline $1990 \ldots \ldots$ & 14 & 870,000 & 0.0006 & 481 & 32,753 & 18,196 & 15,770 & 9,787 & $1,530,000$ \\
\hline $1991 \ldots \ldots$ & 13 & 880,000 & 0.0004 & 344 & 22,892 & 12,362 & 10,530 & 16,355 & $1,590,000$ \\
\hline $1992 \ldots \ldots$ & 12 & 950,000 & 0.0003 & 260 & 18,830 & 9,740 & 9,090 & 26,722 & $1,660,000$ \\
\hline $1993 \ldots \ldots$ & 11 & $1,030,000$ & 0.0002 & 194 & 14,057 & 6,488 & 7,137 & 33,971 & $1,720,000$ \\
\hline $1994 \ldots \ldots$ & 10 & $1,100,000$ & 0.0001 & 141 & 9,067 & 4,331 & 4,331 & 43,200 & $1,780,000$ \\
\hline $1995 \ldots \ldots$ & 9 & $1,040,000$ & 0.0001 & 89 & 5,251 & 2,387 & 2,228 & 36,925 & $1,830,000$ \\
\hline $1996 \ldots . .$. & 8 & $1,160,000$ & 0.0001 & 66 & 3,251 & 1,494 & 1,362 & 32,531 & $1,870,000$ \\
\hline $1997 \ldots \ldots$ & 7 & $1,230,000$ & 0.0000 & 46 & 1,732 & 798 & 729 & 22,585 & $1,890,000$ \\
\hline $1998 \ldots . .$. & 6 & $1,270,000$ & 0.0000 & 31 & 911 & 367 & 333 & 13,346 & $1,910,000$ \\
\hline $1999 \ldots \ldots$ & 5 & $1,350,000$ & 0.0000 & 21 & 412 & 173 & 158 & 6,713 & $1,910,000$ \\
\hline $2000 \ldots \ldots$ & 4 & $1,300,000$ & 0.0000 & 13 & 182 & 68 & 68 & 3,323 & $1,920,000$ \\
\hline $2001 \ldots \ldots$ & 3 & $1,150,000$ & 0.0000 & 7 & 57 & 20 & 20 & 794 & $1,920,000$ \\
\hline $2002 \ldots \ldots$ & 2 & $1,250,000$ & 0.0000 & 5 & 19 & 9 & 9 & 249 & $1,920,000$ \\
\hline $2003 \ldots \ldots$ & 1 & $1,170,000$ & 0.0000 & 3 & 6 & 3 & 3 & 66 & $1,920,000$ \\
\hline $2004 \ldots \ldots$ & 0 & NA & NA & 563,000 & 532,000 & 309,000 & 261,000 & 254,000 & $1,920,000$ \\
\hline
\end{tabular}


contained in old scrap was theoretically generated from the building and construction sector from material placed in service during the period from 1928 through 2003, with the majority of the contributions for each year from a spread of 35 years about the average life of 40 years for material in that sector. In like manner, the consumption datasets for the other sectors were superimposed with Gaussian distributions to generate old scrap generation statistics for 2004 as follows:

- $\quad$ Electrical and electronic products-

- $\quad$ dataset from 1969 through 2003

- $\quad$ average life, 18 years

- $\quad$ spread 16 years

- $\quad$ copper contained in old scrap generated, 532,000 t

- Industrial machinery and equipment-

- $\quad$ dataset from 1969 through 2003

- $\quad$ average life, 18 years

- $\quad$ spread 16 years

- $\quad$ copper contained in old scrap generated, 309,000 t

- Transportation equipment-

- $\quad$ dataset from 1969 through 2003

- $\quad$ average life, 18 years

- $\quad$ spread 16 years

- $\quad$ copper contained in old scrap generated, 261,000 t

- Consumer and general products-

- dataset from 1983 through 2003

- $\quad$ average life, 10 years

- $\quad$ spread 10 years

- $\quad$ copper contained in old scrap generated, 254,000 t

In 2004, the total old scrap theoretically generated from these five sectors contained $1.92 \mathrm{Mt}$ of copper.

Uncertainties in the estimate for old scrap theoretically generated can arise from several factors including:

- average life and variance about the average are themselves estimates

- $\quad$ the datasets for sector consumption may be inaccurately reported

- the datasets for U.S. economic sector consumption may appear to be decreasing with time, which may be an inaccurate snapshot because the copper contained in net imports of finished goods (such as automobiles and appliances) does not appear in consumption accounting, leading to underestimating old scrap generated ${ }^{14}$.

\section{OLD SCRAP UNRECOVERED}

Old scrap unrecovered could be located in several places. It could be abandoned in place (hibernating) pending suitable economic incentives (scrap prices) to warrant collection and processing. It might have been collected and placed in landfills, which would potentially conserve it for a time of better prices.

\footnotetext{
${ }^{14} \mathrm{~A}$ fact that may be more so in the future than presently because the lifetimes for copper-containing goods are greater than the time period that bounds the shift from domestic to foreign production of U.S. consumer goods.
}

It might have been dissipated (that is, dispersed or scattered) during use (for example, as in paints and fertilizers), making it exceptionally difficult and costly to recycle or recover the metal. Lastly, if the method for estimating old scrap generated is wrong, then it may exist in greater or lesser quantities depending on the direction of the estimate error.

Spatari and others (2005) studied copper flows over time with a dynamic model and estimated that the recycling rate for copper from postconsumer waste was 40 percent and that, over the past century, 130 kilograms per capita for the current North American population has been added to landfills.

In figure 10, the term reported as old scrap unrecovered is the amount that closes the material balance after summing inputs and outputs. It is therefore an artifact of the materials flow accounting process. In 2004, copper contained in old scrap unrecovered amounted to $1.15 \mathrm{Mt}$ of copper (about 60 percent of theoretical old scrap generated).

\section{OLD SCRAP RECOVERED AND USED}

Old scrap recovered and reused is based on reported data and is therefore more reliable than the previously discussed estimates pertaining to old scrap generation and disposal. In 2004, 772,000 t (40 percent of old scrap theoretically generated) of copper contained in old scrap was recovered. This was supplemented by 3,000 t of copper contained in a drawdown of old scrap stocks and 80,000 t of copper contained in scrap imports. Of this U.S. supply of old scrap containing 855,000 t of copper, 633,000 t of copper (74 percent of U.S. old scrap supply) was exported, $167,000 \mathrm{t}$ of copper (20 percent of U.S. old scrap supply) was returned to U.S. primary refined copper producers and semifabricators, and 54,000 t of copper (6 percent of U.S. old scrap supply) was consumed by noncopper producers. Gomez and others (2007) studied the relatively low rate of old scrap recovery and suggested that the low rate may be explained by reduced secondary production capacity owing to environmental control costs and the successful efforts of primary producers to reduce their production costs. The study also found that the existence of old scrap stocks was not a driver for old scrap recycling.

\section{NEW SCRAP}

Figure 10 shows that $735,000 \mathrm{t}$ of copper contained in new scrap ( 5 percent from semifabrication copper production and 95 percent from manufacturing operations) was recovered in 2004, of which 712,000 t of copper (97 percent of new scrap supply) was recovered by wire rod mills, brass mills, foundries, and from chemical production; 16,000 $\mathrm{t}$ of copper (2 percent of new scrap supply) was recovered in primary refined copper production; and 7,000 t of copper (1 percent of new scrap supply) was recovered in noncopper operations.

In 2004, the new-scrap-to-old-scrap ratio with respect to scrap consumed in U.S. manufacturing activities was 3.2 
(table 1). Home scrap, which is scrap generated and recovered within the same plant, was not included in this analysis.

\section{SCRAP RECYCLING EFFICIENCY}

Based on the amount of copper contained, old scrap recycling efficiency was estimated to be 43 percent of theoretical old scrap supply (fig. 1) from the following formula:

consumption of old scrap + exports of old scrap

old scrap generated + imports of old scrap + decrease of old scrap stocks

or

$$
\frac{230,000 \mathrm{t}+633,000 \mathrm{t}}{1.92 \mathrm{Mt}+80,000 \mathrm{t}+3,000 \mathrm{t}}
$$

When the new scrap recovery and consumption are considered, 735,000 t of additional copper from scrap is recovered, and the overall scrap recycling efficiency is 58 percent of the copper contained in the theoretical supply of old and new scrap combined.

\section{SCRAP RECEIPTS AT U.S. PRIMARY AND SEMIFABRICATION COPPER PRODUCERS}

In 2004, total U.S. supply of copper recoverable from scrap (new and old) was $1.59 \mathrm{Mt}$ of contained copper, composing 772,000 $\mathrm{t}$ of copper recovered from old copper scrap generated, 3,000 t of copper from reduced stocks, 80,000 $\mathrm{t}$ of copper from imports, and 735,000 $\mathrm{t}$ of copper contained in new scrap generated. Of the $1.59 \mathrm{Mt}$ of recoverable copper, $895,000 \mathrm{Mt}$ of recoverable copper (56 percent of supply) was received by U.S. mills for consumption and inventory adjustment, 633,000 t of contained copper (40 percent of supply) was exported, and $61,000 \mathrm{t}$ of recoverable copper (4 percent of supply) was received and consumed by noncopper producers.

Of the 895,000 $\mathrm{t}$ of copper recoverable from scrap that was received at U.S. refined-copper producers and copper-product semifabricators, 845,000 t (94 percent) was consumed by semifabricators, and 51,000 t (6 percent) was consumed to produce refined copper. The 845,000 t of copper consumed by semifabricators was supplemented with 9,000 $\mathrm{t}$ of copper contained in a drawdown of semifabricators' scrap inventories for a total input to semifabrication of $853,000 \mathrm{t}$ of recoverable copper, which was distributed for production among semifabricators as follows: brass mills consumed 679,000 t (79 percent), ingot makers consumed 90,000 $\mathrm{t}$ (11 percent), foundries and others consumed $57,000 \mathrm{t}$ (7 percent), and wire rod mills consumed 26,000 $\mathrm{t}$ ( 3 percent).

\section{PROCESSING OF COPPER SCRAP}

The collection and handling of new copper scrap are fairly straightforward. New scrap is generated during manufacturing operations and consists of items such as clippings, stampings, and turnings. These are usually segregated by material specification and returned to furnace operations where the scrap is matched and melted for reuse based on its chemistry. Some new scrap enters the open market, but the major portion is returned to the primary and secondary mills through buy-back arrangements.

Old scrap originates from product aging within the reservoir of products-in-service. Old scrap requires more handling, including operations such as collection, manual sorting, stripping, shredding, and magnetic separation. The scrap may be compacted into a bundle or briquette.

Copper wire scrap contains about 60 percent metal and 40 percent polyvinylchloride insulation, which must be separated before the copper wire can be recovered completely. Insulation can be removed from wire with very fine chopping. The process produces a fine-particle mixture of insulation and wire, which is passed over a fluidized bed to facilitate the separation of the insulation (overflow) from the wire (underflow). Another separation process is cable stripping, which is a much slower process, where the cable is passed through a machine that separates the insulation from single strands of wire (Bureau of International Recycling, 2008). The product of wire stripping/chopping operations is usually a high-quality scrap, "bare bright" as listed by ISRI, and may trade at a premium to refined cathode as its size distribution makes it easier to process.

Cell phones and computers are sources of electronic scrap. In 2004, about 2,900 t of copper was contained in cell phones in-use (Sullivan, 2006). In 1999, Noranda, Inc. of Canada received 50,000 t of electronic scrap from more than 300 suppliers in 18 countries for addition to its smelting furnaces; in 1998, about 4,600 t of copper was recovered from such scrap (Bleiwas and Kelly, 2001). Electronic scrap is also attractive for its content of precious metals.

Complicated residues, such as drosses, liquors, skimmings, slags, and spent electrolytes, are usually treated in specially designed recovery circuits with chemical control and assorted separation technologies.

\section{COPPER SCRAP TRADE}

Large quantities of copper contained in various forms and mixtures move through the international scrap trade. In 2004, 633,000 $\mathrm{t}$ of copper contained in 714,000 $\mathrm{t}$ of old scrap $^{15}$ was exported from the United States, which was the

\footnotetext{
${ }^{15}$ It is assumed that old scrap is what is being traded because new scrap tends to flow backwards through the production process by agreement and contract.
} 
leading source of global copper scrap exports, accounting for 19 percent of global scrap trade (Edelstein, 2007, p. 21.5). Figure 11 shows the distribution of those exports by country.

Most of the old copper scrap exported by the United States goes to Asia, and China, by far, is the largest consumer. The emergence of China as a significant importer of U.S. old scrap is a relatively new phenomenon driven by increasing Chinese demand for copper raw materials and the reduction of domestic demand because of the closure of significant scrap smelting capacity for economic and environmental reasons. Figure 12 shows the growth of exports to China of both unalloyed and alloyed U.S. old copper scrap from 1995 through 2004.

From 1995 through 2004, total U.S. old copper scrap exports to China grew by about 50 percent per year. Unalloyed scrap exports grew by about 70 percent per year, and alloyed scrap exports, by about 34 percent per year. The value of this trade increased to $\$ 477$ million in 2004 from $\$ 90$ million in 1995 (48 percent per year).

The United States is also an importer of old copper scrap. In 2004, 80,000 t of copper contained in such scrap was imported. Figure 13 shows the distribution of sources for U.S. imports of old copper scrap.

Most U.S. imports of old copper scrap originate in North America and Central America. Overall, the United States

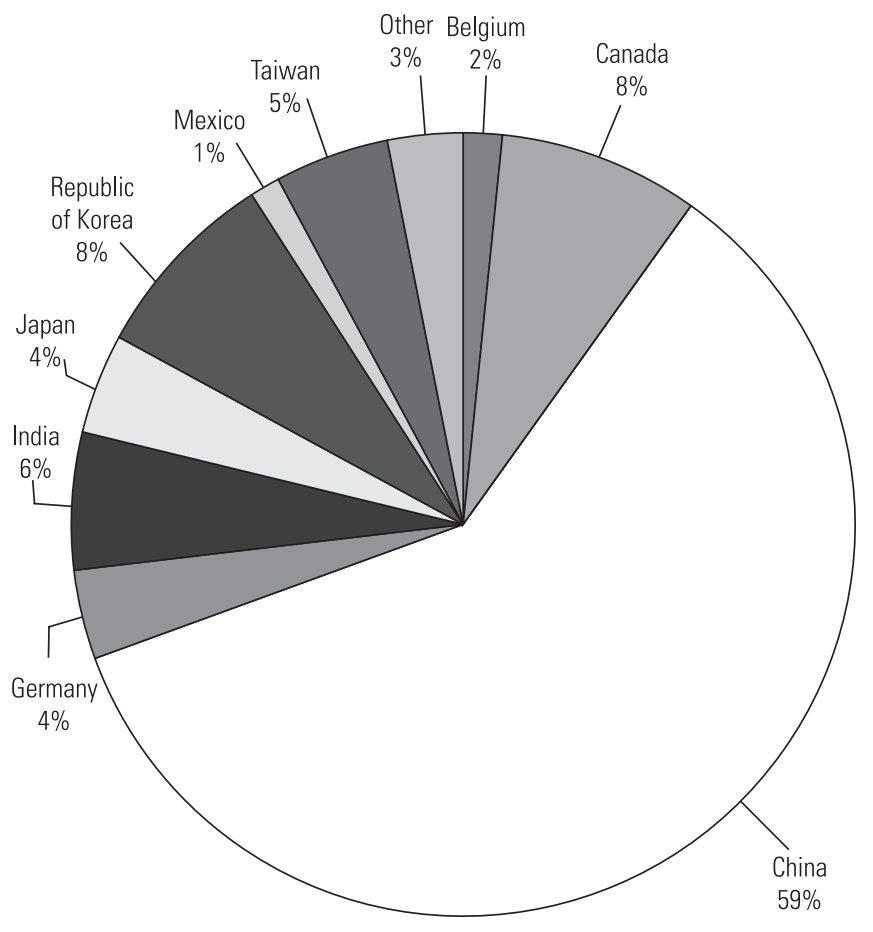

Figure 11. Chart showing the distribution of exports of old copper scrap from the United States in 2004, by country. Values are in percentage of total exports. Source: Edelstein, 2007.

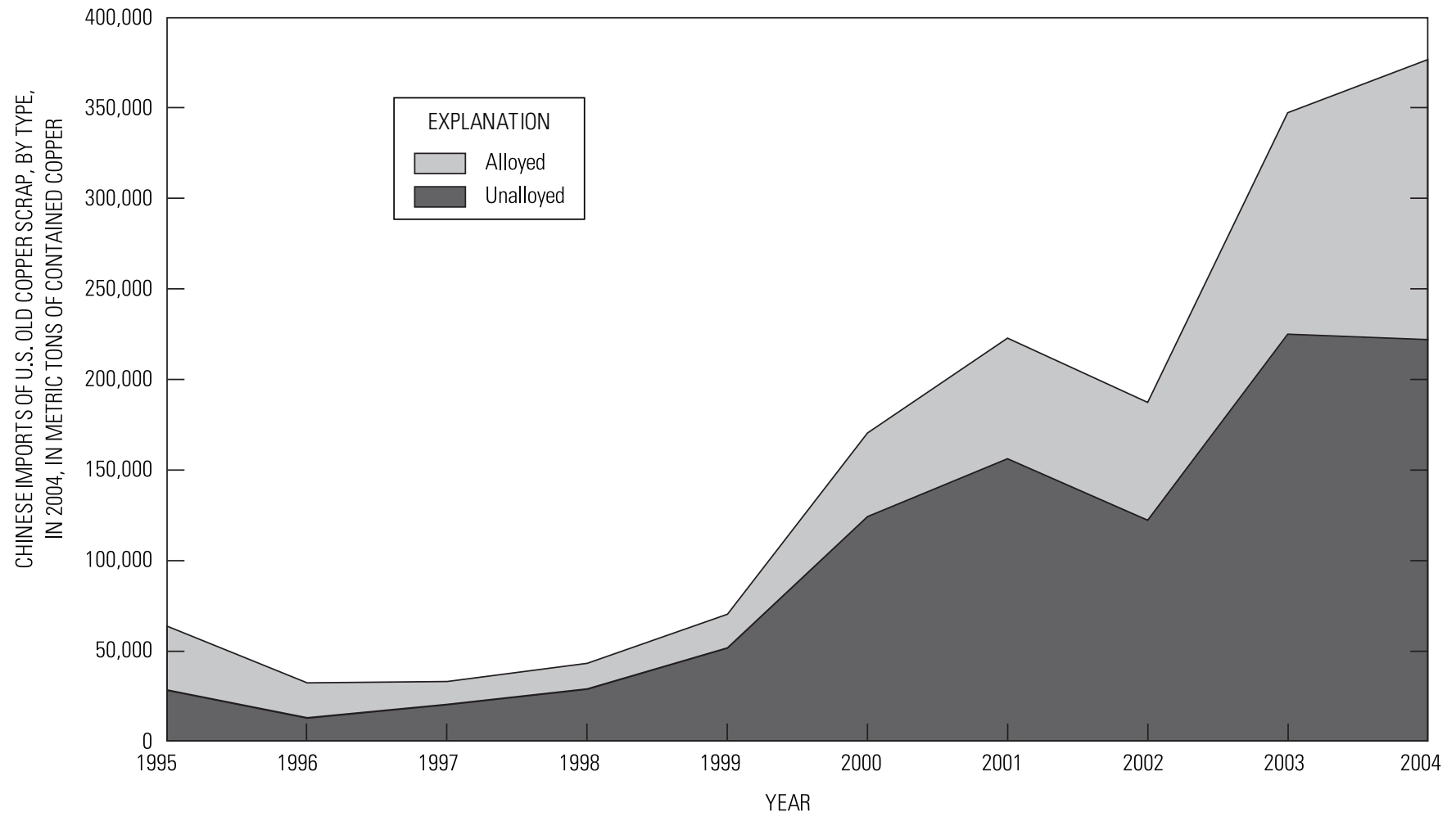

Figure 12. Chart showing Chinese imports of U.S. old copper scrap from 1995 through 2004, by type. Values are in metric tons of contained copper. Source: Edelstein, 1998-2007. 


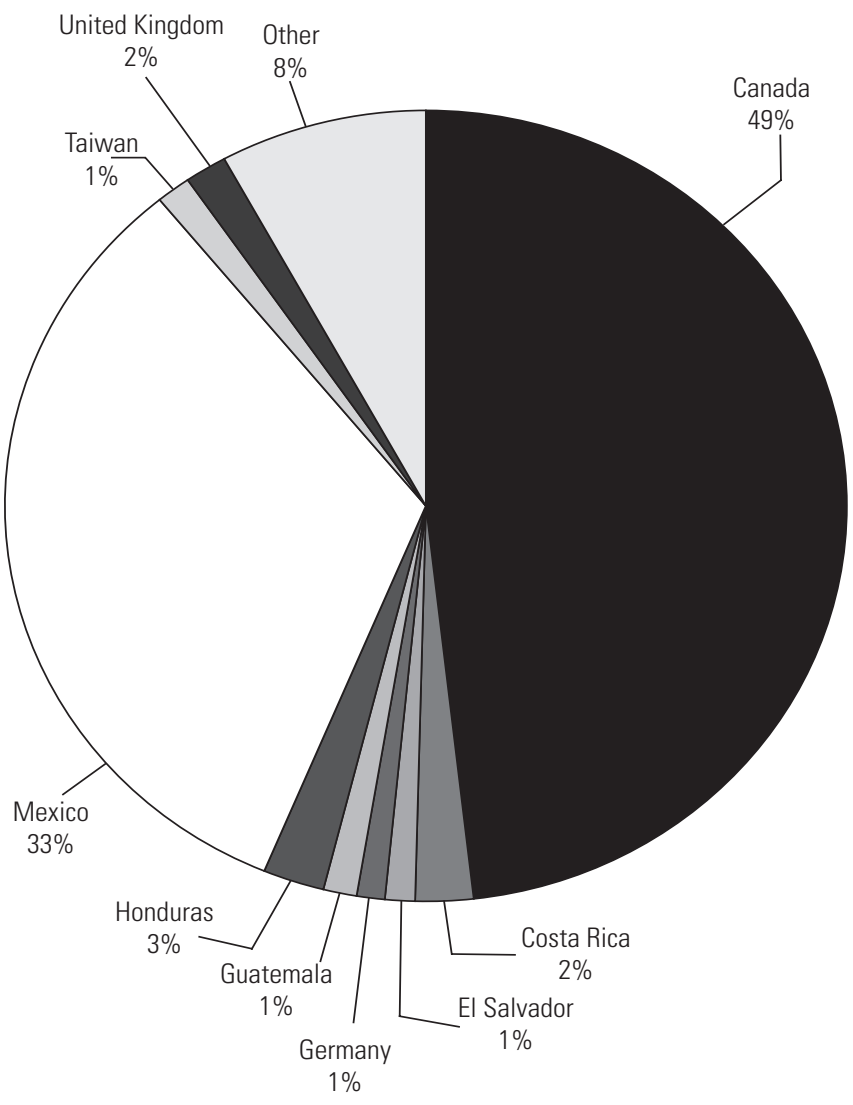

Figure 13. Chart showing distribution of sources for U.S. imports of old copper scrap in 2004. Values are in percentage of total imports. Source: Edelstein, 2007, table 19.

was a net exporter of copper $(553,000 \mathrm{t})$ contained in scrap in 2004.

\section{OUTLOOK}

Because of the superior electrical properties of copper, it should continue to be in demand worldwide. In-ground copper resources seem adequate because copper prices, which should be rising under a condition of supply and demand mismatch, are near their 100-year averages in terms of constant dollars. High prices for copper will enhance recovery of copper from scrap. Economic globalization seems to be redistributing flows for all copper-bearing materials_-anode, concentrate, ore, product, and scrap.

The reduction of production costs by means of incremental technological improvements should continue as a typical response to the pressure of the increasing costs of energy, labor, and material inputs. Stakeholders could be expected to push for improved resource efficiencies through recycling mandates where the economics may not justify recycling. The loss of U.S. copper processing capacity may not necessarily decrease copper recycling. Recycling should continue but may increasingly occur in foreign countries, which would be importing U.S. scrap. Competition from other material streams should continue to create challenges for securing the energy and material inputs necessary to sustain copper production. Competition of other materials for the traditional share of copper in market end uses should help to provide a counterbalance.

\section{REFERENCES CITED}

American Metal Market, 2007, Database (prices)—Response to special query for period January, 1997 through February, 2007, for nonferrous scrap, copper; dealer; number 1 heavy and wire, and auto radiators (unsweated): American Metal Market Web site, accessed January 4, 2008, by subscription at URL http://amm.com/priorprice/matprice.asp.

Anchor Bronze and Metals, Inc., 2007, Copper alloy database: Anchor Bronze and Metals, accessed February 2, 2007, at URL http://www.anchorbronze.com/alloydatabase.htm. [From this page, select any copper alloy by its categorical alloy name and corresponding Unified Numbering System alloy number.]

Automation Creations, Inc., 2007, Material property data $\left(\mathrm{MatWeb}^{\odot}\right.$ ): Automation Creations Web site, accessed February 6, 2007, at URL http://www.matweb.com/index.asp?ckck=1. [From this page, select "alloy composition" and specify a range for subject elements.]

Baker, S.R., 2007, Assessing recycling rates in the copper industry: Non-Ferrous Metals Consultative Forum on Sustainable Development, 17 p., accessed January 29, 2007, at URL http://www.nfmsd.org/details/files/ Scott_Baker_presentation.pdf.

Bhadeshia, H.K.D.H., 2005, Metallurgy of bronze bells and castings: University of Cambridge, accessed August 18, 2008, at URL http://www.msm.cam.ac.uk/phase-trans/2005/bell/bell.html.

Bleiwas, D. I., and Kelly, T.D., 2001, Obsolete computers, "gold mine" or high-tech trash?-Resource recovery from recycling: U.S. Geological Survey Fact Sheet 060-01, 4 p., accessed January 10, 2008, at URL http://pubs.usgs.gov/fs/fs060-01/ fs060-01.pdf.

Bureau of International Recycling, 2008, Plastic coated cable scrap: Bureau of International Recycling, accessed January 10, 2008, at URL http://www.bir.org/aboutrecycling/cable/index.asp.

Burghardt, Jeffery, 2004, Testimony before the Bureau of Industry and Security, United States Department of Commerce: Electronic Freedom of Information Act, May 19, 4 p., accessed January 11, 2008, at URL http://efoia.bis.doc.gov/shortsupply/ burghardt.pdf.

Callcut, Vin, 2006, High copper alloys-High-strength coppers for demanding electrical applications: [Copper Development Association, Inc.] Innovations, September, 9 p., accessed January 26, 2007, at URL http://www.copper.org/ innovations/2006/09/high_cu_alloys.html.

Canadian Centre for Occupational Health and Safety, 1999, Nonsparking tools: Canadian Centre for Occupational Health and Safety Web site, accessed January 11, 2008, at URL http://www.ccohs.ca/oshaanswers/safety_haz/hand_tools/ nonsparking.html.

Carlin, J.F., Jr., 2006, Tin, in Metals and minerals: U.S. Geological Survey Minerals Yearbook 2004, v. I, p. 77.1-77.14, accessed 
January 11, 2009, at URL http://minerals.er.usgs.gov/minerals/ pubs/commodity/tin/tinmyb04.pdf.

Copper Development Association Inc., 2005, Annual data 2004Copper supply and consumption: New York, N.Y., Copper Development Association Inc., 21 p.

Copper Development Association, 2007a, Chromium copper: Copper Development Association Web site, accessed January 26, 2007, at URL http://www.copper.org/resources/properties/ microstructure/chrom_cu.html.

Copper Development Association, 2007b, Copper nickels: Copper Development Association Web site, accessed January 26, 2007, at URL http://www.copper.org/resources/properties/ microstructure/cu_nickel.html.

Copper Development Association, 2007c, Copper tin alloys: Copper Development Association Web site, accessed January 26, 2007, at URL http://www.copper.org/resources/properties/ microstructure/cu_tin.html.

Copper Development Association, 2007d, Nickel silvers: Copper Development Association Web site, accessed January 26, 2007, at URL http://www.copper.org/resources/properties/ microstructure/ni_silver.html.

Copper Development Association, 2008, Aluminum bronzes: Copper Development Association Web site, accessed January 26, 2007, at URL http://www.copper.org/resources/properties/ microstructure/al_bronzes. (Accessed August 18, 2008.)

Cowen, Richard, 2008, The bronze age, chap. 4 of Exploiting the earth: Johns Hopkins University Press, 11 p., accessed at URL http://www.geology.ucdavis.edu/ cowen/ GEL115/ 115CH4.html.)

Cox, D.P., Schmidt, R.G., Vine, J.D., Kirmenko, Harold, Tourtelot, E.B. and Fleischer, Michael, 1973, Copper, in Brobst, D.A., and Pratt, W. P., eds., United States Mineral Resources: U.S. Geological Survey Professional Paper 820, p. 166-180, accessed May 15, 2009, at URL http://pubs.er.usgs.gov/djvu/ PP/pp_820.djvu.

Cunningham, L.D., 2003, Beryllium recycling in the United States in 2000, in Sibley, S.R., ed., Flow studies for recycling metal commodities in the United States: U.S. Geological Survey Circular 1196-P, p. P1-P15, accessed May 15, 2009, at URL http://pubs.usgs.gov/circ/c1196p/c1196p.pdf.

Department of Environment and Water Resources, Australia, 2007, Copper and compounds fact sheet, in National Pollutant Inventory database: Department of Environment and Water Resources, Australia Web site, accessed January 26, 2007, at URL http://www.npi.gov.au/database/ substance-info-profiles/27.html.

Edelstein, D.L., 1998, Copper, in Metals and minerals: U.S. Geological Survey Minerals Yearbook 1996, v. I, p. 22.1-22.28, accessed May 15, 2009, at URL http://minerals.er.usgs.gov/minerals/ pubs/commodity/copper/240496.pdf.

Edelstein, D.L., 1999, Copper, in Metals and minerals: U.S. Geological Survey Minerals Yearbook 1997, v. I, p. 22.1-22.28, accessed May 15, 2009, at URL http://minerals.er.usgs.gov/minerals/ pubs/commodity/copper/240497.pdf.

Edelstein, D.L., 2000, Copper, in Metals and minerals: U.S. Geological Survey Minerals Yearbook 1998, v. I, p. 22.1-22.28, accessed May 15, 2009, at URL http://minerals.er.usgs.gov/minerals/pubs/commodity/ copper/240498.pdf.
Edelstein, D.L., 2001, Copper, in Metals and minerals: U.S. Geological Survey Minerals Yearbook 1999, v. I, p. 22.1-22.29, accessed May 15, 2009, at URL http://minerals.er.usgs.gov/minerals/pubs/commodity/ copper/240499.pdf.

Edelstein, D.L., 2002, Copper, in Metals and minerals: U.S. Geological Survey Minerals Yearbook 2000, v. I, p. 23.1-23.25, accessed May 15, 2009, at URL http://minerals.er.usgs.gov/minerals/pubs/commodity/ copper/240400.pdf.

Edelstein, D.L., 2003, Copper, in Metals and minerals: U.S. Geological Survey Minerals Yearbook 2001, v. I, p. 22.1-22.27, accessed May 15, 2009, at URL http://minerals.er.usgs.gov/minerals/pubs/commodity/copper/ coppmyb01.pdf.

Edelstein, D.L., 2004, Copper, in Metals and minerals: U.S. Geological Survey Minerals Yearbook 2002, v. I, p. 22.1-22.28, accessed May 15, 2009, at URL http://minerals.er.usgs.gov/minerals/pubs/commodity/copper/ coppmyb02r.pdf.) (Accessed May 15, 2009.)

Edelstein, D.L., 2005, Copper, in Metals and minerals: U.S. Geological Survey Minerals Yearbook 2003, v. I, p. 21.1-21.27, accessed May 15, 2009, at URL http://minerals.er.usgs.gov/minerals/pubs/commodity/copper/ coppmyb03.pdf.) (Accessed May 15, 2009.)

Edelstein, D.L., 2007, Copper, in Metals and minerals: U.S. Geological Survey Minerals Yearbook 2004, v. I, p. 21.1-21.27, accessed May 15, 2009, at URL http://minerals.er.usgs.gov/minerals/pubs/commodity/copper/ coppemyb04.pdf.) (Accessed May 15, 2009.)

Futures Trading Charts, 2007, Copper high-grade (HG, Comex), monthly price chart: Futures Trading Charts Web site, accessed January 4, 2008, at URL http://futures.tradingcharts.com/chart/CP/M/ ? saveprefs $=$ t $\&$ x showdata $=$ t $\&$ x Chartty pe $=$ b \& $x$ hide $\mathrm{specs}=\mathrm{f} \& \mathrm{xhide} \_$analysis $=\mathrm{f} \& \mathrm{xhide} \_$survey $=\mathrm{t} \& \mathrm{xhide} \_$news $=\mathrm{f}$.

Goonan, T.G., 2004, Flows of selected materials associated with world copper smelting: U.S. Geological Survey Open-File Report 2004-1395, 138 p., accessed June 18, 2009, at URL http://pubs.usgs.gov/of/2004/1395/.

Gomez, Fernando, Guzman, J.I., and Tilton, J.E., 2007, Copper recycling and scrap availability: Resources Policy, n. 32, August, p. 183-190, accessed by subscription at URL http://www.sciencedirect.com/.

Greetham, Geoff, 2003, Copper applications in industrial and marine applications: Copper Development Association Web site, accessed September 27, 2006, at URL http://www.copper.org/ innovations/2003/11/Cu_hull_sheathing_gg.htm.

International Cadmium Association, 2007, All information on cadmium-Cadmium in alloys: International Cadmium Association Web site, accessed February 7, 2007, at URL http://www.cadmium.org/app_allo.html.

International Copper Study Group, 2005a, ICSG's copper flow model-Determining recycling rates for the United States: Lisbon, Portugal, International Copper Study Group, draft status report, November, 38 p.

International Copper Study Group, 2005b, ICSG's copper flow model-Determining recycling rates for Western Europe: Lisbon, Portugal, International Copper Study Group, final report, March, $90 \mathrm{p}$. 
Jolly, J.L., 2006, The U.S. copper-base scrap industry and its byproducts, 2005 (6th ed.): New York, N.Y., Copper Development Association, Inc. Technical Report A1039-02/00, 81 p. (Also available at URL http://www.copper.org/resources/pub_list/ pdf/scrap_report.pdf.

Jorgenson, J.D., 2007, Zinc, in Metals and minerals: U.S. Geological Survey Minerals Yearbook 2004, v. I, p. 84.1-84.25, accessed May 15, 2009, at URL http://minerals.er.usgs.gov/minerals/pubs/commodity/zinc/ zinc_myb04.pdf.

Kelly, T.D., and Matos, G.R., 2006, Copper-End use statistics, in Historical statistics for mineral and material commodities in the United States: U.S. Geological Survey Data Series 140, accessed May 12, 2006, at URL http://minerals.usgs.gov/ds/2005/140/.

Kuck, P.H., 2007, Nickel, in Metals and minerals: U.S. Geological Survey Minerals Yearbook 2004, v. I, p. 52.1-52.27, accessed May 15, 2009, at URL http://minerals.er.usgs.gov/minerals/pubs/commodity/nickel/ nickemby04.pdf.

Morrow, Hugh, 2005, Cadmium: Mining Journal Review Web site, accessed February 7, 2007, at URL http://www.mmta.co.uk/ economicsFacts/Articles/MiningJournalReview/Cadmium.pdf.

Parker, R.L., 1967, Composition of the Earth's crust, chap. D of Fleischer, Michael, ed., Data of geochemistry [6th ed.]: U.S. Geological Survey Professional Paper 440-D, 19 p.

Phelps Dodge Corporation, 2007, Technology_Process technology: Phelps Dodge Corporation Web site, accessed January 29, 2007, at URL http://www.phelpsdodge.com/AboutUs/ Ourcompanies/Mining/Technology.htm.

Shedd, K.B., 2008, Beryllium, in Metals and minerals: U.S. Geological Survey Minerals Yearbook 2005, v. I, p. 11.1-11.10, accessed May 15, 2009, at URL http://minerals.er.usgs.gov/minerals/pubs/commodity/ beryllium/berylmyb05.pdf.

Singer, D.A., Berger, V.I., and Moring, B.C., 2002, Porphyry copper deposits of the world-Database, maps, and preliminary analysis: U.S. Geological Survey Open-File Report 02-268, 61 p., accessed June 18, 2009, at URL http://geopubs.wr.usgs.gov/open-file/of02-268/.

Smiths Metal Centers, 2006, Nickel silver: Smiths Metal Centers Web site, accessed December 8, 2006, at URL http://www.smithmetal.com/products/nickelsilver.htm.
Spatari, S., Bertram, A., Gordon, R.B., Henderson, K., and Graedel, T.E., 2005, Twentieth century copper stocks and flows in North America-A dynamic analysis: Ecological Economics, no. 54, May, p. 37-51, accessed July 23, 2007, by subscription at URL http://www.sciencedirect.com/.

Sullivan, D.E., 2006, Recycled cell phones-A treasure trove of valuable metals: U.S. Geological Survey Fact Sheet 2006-3097, 4 p., accessed May 15, 2009, at URL http://pubs.usgs.gov/fs/2006/3097/.

Taylor, Alan, and Jansen, M.S., 2000, Hydrometallurgical treatment of copper sulphides-Are we on the brink: Alta Metallurgical Services, 8 p., accessed January 29, 2007, at URL http://www.altamet.com.au/Technical_Papers_and_Articles/ Alta_Copper/Are_We_on_the_Brink.pdf.

Taylor, Alan, 2002, Big guns now in copper concentrate leaching race: Alta Metallurgical Services, 4 p., accessed January 29, 2007, at URL http://www.altamet.com.au/ Technical_Papers_and_Articles/Minerals_Gazette/ Big_Guns_in_Copper_Conc_Leaching_Race.pdf.

U.S. Bureau of Mines, 1968, Porphyry copper, in Dictionary of mining, mineral, and related terms: U.S. Bureau of Mines, 1269 p.

U.S. Environmental Protection Agency, 1995, Secondary copper smelting, in Compilation of air pollutant emission factorsMetallurgical industry: U.S. Environmental Protection Agency, v. 1, p. 12.9-1-12.9-9, accessed December 4, 2007, at URL http://www.epa.gov/ttn/chief/ap42/ch12/final/c12s09.pdf.

U.S. Geological Survey, 1999, Copper, in Metal prices in the United States through 1998: U.S. Geological Survey, p. 39-42, accessed May 15, 2009, at URL http://minerals.er.usgs.gov/ minerals/pubs/metal_prices/.

U.S. Geological Survey, 2004, Mineral commodity summaries 2004: U.S. Geological Survey, 197 p.

U.S. Geological Survey, 2005, Mineral commodity summaries 2005: U.S. Geological Survey, 197 p.

U.S. Geological Survey, 2006, Mineral commodity summaries 2006: U.S. Geological Survey, 199 p.

Vlaamse Technische Kring, 2006, Electrorefining copper: Catholic University of Leuven [Belgium] Web site, accessed November 28, 2007, at URL http://mech2006.vtk.be/downloads/ mech2005/1e/materiaalkunde/5-b_copper.pdf. 


\section{APPENDIX-DEFINITIONS}

anode. The positive terminal in an electrolytic cell where electrons leave a device to enter the external circuit. A copper anode at 99 percent purity will dissolve.

anode slimes. A mixture of metals and some insoluble compounds that originate in and dissolve from the anode during electrolysis and precipitate from the electrolyte onto the cell floor. These are processed for the metal content. In copper electrolysis, gold, silver, selenium, tellurium, and other metals are recovered.

apparent consumption. Primary plus secondary production (old scrap) plus imports minus exports plus adjustments for U.S. Government and industry stock changes.

apparent supply. Apparent consumption plus consumption of new scrap.

blister copper. The product of a converting furnace. It is an intermediate, more concentrated (with respect to the desired metal) material than matte, from which it is made, and is usually transferred to another furnace for further concentration. Blister copper contains about 98 percent copper, the exact percentage depending on the process parameters. Blister copper is sometimes cast into ingot forms and placed into worldwide trade. Most often it is fire-refined onsite.

cathode. The negative terminal in an electrolytic cell where copper is plated during electrowinning or electrolytic refining. Copper so plated is referred to as "cathode" and is generally about 99.99 percent pure.

catenary. The name of the curve formed by a uniform cable strung between two points. It is mathematically described by a hyperbolic function.

copper concentrate. A product of flotation milling. It composes sulfide minerals and entrained material and contains one-third each copper, iron, and sulfur. It can be processed pyrometallurgically in a smelter to produce matte or hydrometallurgically (pressure leaching) to produce pregnant leach solution, both products requiring further processing to obtain copper metal. Copper concentrate may participate in worldwide trade or be smelted domestically in its country of origin.

electrolyte. An acidic solution containing copper ions. In electrorefining, the concentration of copper ions remains relatively constant, in balance with copper dissolution at the anode and copper precipitation at the cathode. In electrowinning, the copper concentration is more variable but in relative equilibrium with new copper ions introduced by rich (copper-loaded) electrolyte from the solvent extraction facility and with the copper precipitation at the cathode.

electrorefining. An electrolytic refining process where less pure copper anodes are dissolved, and high-purity copper is plated at the cathode. electrowinning. An electrolytic refining process where the anode is inert, and rich (copper-loaded) electrolyte continually replaces lean (copper-depleted) electrolyte as copper is plated at the cathode.

fire-refined copper. The product of a fire-refining furnace. It is an intermediate, more concentrated (with respect to the desired metal) material than blister, from which it is made. Because oxygen is added in the processing to upgrade the copper content by oxidizing the impurities in the furnace charge materials, the resulting copper must be deoxidized, usually by stirring it with natural gas, with the carbon in the natural gas reacting with the excess oxygen. Fire-refined copper contains about 99 percent copper, the exact percentage depending on the process parameters. Fire-refined copper is sometimes cast into ingot forms and placed into worldwide trade. Often it is transferred to another same-company electrorefining facility for processing into 99.99 percent copper cathode. Fire-refining is also used to purify high-grade copper scrap consumed at brass mills in the production of tube and sheet products.

flotation. A method of mineral separation in which air and a variety of reagents are injected to create a froth in water. Some finely crushed minerals float and other minerals sink. The preferential flotation of sulfide minerals and sinking of the gangue materials is used to concentrate the copper for economic smelting. The resulting product is called "concentrate."

flux. Slag-making materials, such as sand, lime, limestone, that are added to high-temperature metal and metaloxide emulsions to fuse the oxides into a relatively low melting-point material that can be readily separated from the molten metal.

Gaussian distribution. The utility of materials in service is assumed to decay, thereby generating old scrap, according to a Gaussian distribution. The distribution is generated from the following formula:

$$
y=\frac{1.6}{b} e^{-8\left[\frac{y-a}{b}\right]^{2}}
$$

where $y$ is the year for which the distribution value is being calculated, a is the average life of the material, and $b$ is the spread, a value that is subjectively adjusted but is about two times the average life of the material.

hibernating scrap. Scrap that has reached the end of its useful economic life but has not been collected (remains in place) pending economic conditions that warrant the effort to collect it.

home scrap. Scrap generated as process or runaround scrap and consumed in the same plant where generated. It does not enter into trade and is not considered in this study.

hydrometallurgy. A process of separating desired metals from aqueous solutions. 
lift. The portion of a heap leach that is currently being leached. In common practice, lifts vary in height between 30 and 150 meters and can actively accommodate leaching fluids for 90 to 120 days. The top area of a lift is usually greater than 15,000 square meters.

master alloys (of copper). Alloys with other elements containing more than 10 percent by weight copper. Master alloys serve as an intermediate material source in the manufacture of other alloys or to deoxidize liquid metal baths. The copper content on average ranges between 30 and 90 percent in master alloys.

matte. Is an intermediate, more concentrated (with respect to the desired metal) material than concentrate, from which it is made, and is usually transferred to another furnace for further concentration. Copper mattes contain between 50 and 70 percent copper, depending on the process parameters.

mine waste. Rock materials that are not ore grade and are removed to provide access to ore and disposed.

new scrap (prompt scrap). Scrap produced during the manufacture of metals and articles for both intermediate and ultimate consumption, including all defective finished or semifinished articles that must be reworked, and is obtained from a facility separate from the recycling refiner, smelter, or processor. Examples of new scrap are borings, castings, clippings, drosses, skims, and turnings. Included as new scrap is prompt industrial scrap-scrap obtained from a facility separate from the recycling refiner, smelter, or processor. Excluded from new scrap is home scrap that is generated as process scrap and used in the same plant.

new-to-old-scrap ratio. New scrap consumption compared with old scrap consumption in the United States, measured in weight and expressed as new scrap divided by old scrap.

nominal price. The price at the time of sale.

obsolete (end-of-service-life). A material becomes obsolete when it no longer provides the desired services or when other services are valued more than those provided by the material in question.

old scrap. Scrap including (but not limited to) metal articles that have reached the end of their service life. Old scrap may be collected or stored for recycle, disposed in landfills, simply abandoned, or retained (hibernating scrap) in place. Typical examples of old scrap are electrical wiring, lead-acid batteries, silver from photographic materials, metals from shredded cars and appliances, used aluminum beverage cans, spent catalysts, and tool bits. This is also referred to as postconsumer scrap and may originate from industry or the general public. Expended and obsolete materials used dissipatively, such as paints and fertilizers, are not included.

old scrap exports. The amount of old scrap exported from the United States in a subject year. old scrap generated. The metal content of obsolete products from the U.S. product reservoir that theoretically becomes available for recycling in a subject year.

old scrap imports. The amount of old scrap imported to the United States in a subject year.

old scrap recovered and used. Equals old scrap reported as recovered.

old scrap recycling efficiency. The amount of old scrap recovered and reused relative to the amount available to be recovered and reused. Defined as [consumption of old scrap (COS) plus exports of old scrap (OSE)] divided by [old scrap generated (OSG) plus imports of old scrap (OSI) plus a decrease in old scrap stocks (OSS) or minus an increase in old scrap stocks], measured in weight and expressed as a percentage as follows:

$\frac{\text { COS + OSE }}{\text { OSG }+ \text { OSI }+ \text { decrease in OSS or - increase in OSS }} \times 100$

old scrap unrecovered. Scrap that might have been abandoned in place (hibernating), collected and landfilled, or dissipated during use. It is the difference between theoretical scrap generated and actual scrap collected and processed for sale to the global pool of manufacturers.

organics. Is a term used to describe a mixture of kerosene and proprietary hydrocarbons that specifically adhere to copper in copper hydrometallurgical processes. The organics preferentially load copper from the pregnant leach solution in one tank and unload the copper to lean electrolyte in another tank.

pH. Hydrogen concentration in an acidic solution, a measure of acidity, and a process control parameter in electrolytic processes.

pregnant leach solution. The metal-loaded acidic solution collected in a lined pond following percolation of acid through leachable ore piles. It is the feedstock for solvent-extraction operations.

primary copper. Copper extracted from ores and recovered as copper metal or copper-bearing chemicals.

product reservoir. The stock of copper-bearing materials serving consumer needs. When materials within the product reservoir reach their end of life (end of utility), they become eligible for utility upgrade, one method of which is recycling as old scrap.

pyrometallurgy. A process of separating desired metals from materials under conditions of high heat.

raffinate. The copper-depleted flow back to the heap leach after the copper-rich pregnant leach solution has been stripped of its copper load through solvent extraction.

recoverable copper. The flows reported here are flows of recoverable copper; that is, they are reported in terms of the copper contained in products. There are dissipative losses to air, water, and land throughout the system, but these are not quantified. This approach makes the system 
appear to balance, but the reality is that more copper (to cover the dissipative losses) than is reported is required to produce the product reported.

recycling. A process to reclaim a metal (for example, copper) in a useable form from scrap or wastes. This includes recovery as the refined metal or as alloys, compounds, or mixtures that are useful. Examples of recycling are recovery of copper from such copper-bearing alloys as brass, from spent, from copper-sulfate solutions, and even from low-grade wastes, such as drosses, dusts, skimmings, and slag.

recycling rate. The fraction of the apparent metal supply that is scrap on an annual basis. It is defined as [consumption of old scrap (COS) plus consumption of new scrap (CNS)] divided by apparent supply (AS), measured in weight and expressed as a percentage:

$$
\frac{\mathrm{COS}+\mathrm{CNS}}{\mathrm{AS}} \times 100
$$

scrap consumption. Scrap added to the production flow of a metal or metal product.

secondary copper. Copper recovered from scrap and waste. Scrap types include clippings, cuttings, grindings, turnings, flue dust, slag, filter cakes, and spent electrolyte solutions.

supply of recoverable copper. The sum of new (prompt) scrap, old scrap recovered, old scrap imports, and old scrap stock decrease. This supply serves the domestic and foreign demand for scrap. 